\title{
Litter quality and its response to water level drawdown in boreal peatlands at plant species and community level
}

\section{Strakova, Petra}

2010

Strakova , P , Anttila , J , Spetz , P , Kitunen , V , Tapanila , T \& Laiho , R 2010 , ' Litter quality and its response to water level drawdown in boreal peatlands at plant species and community level ' , Plant and Soil , vol. 335 , no. 1-2 , pp. 501-520 . https://doi.org/10.1007/s11104-010-0447-6

http://hdl.handle.net/10138/27408

https://doi.org/10.1007/s11104-010-0447-6

acceptedVersion

Downloaded from Helda, University of Helsinki institutional repository.

This is an electronic reprint of the original article.

This reprint may differ from the original in pagination and typographic detail.

Please cite the original version. 
Published in Plant and Soil, vol. 335, pages 501-520, 2010.

doi: 10.1007/s11104-010-0447-6

\title{
Litter quality and its response to water level drawdown in boreal peatlands at plant species and community level
}

\author{
Petra Straková $^{\mathrm{a}, \mathrm{b}}$, Jani Anttila $^{\mathrm{a}}$, Peter Spetz ${ }^{\mathrm{b}}$, Veikko Kitunen ${ }^{\mathrm{b}}$, Tarja Tapanila ${ }^{\mathrm{b}}$, and \\ Raija Laiho ${ }^{\text {a }}$ \\ ${ }^{a}$ Peatland Ecology Group, Department of Forest Sciences, University of Helsinki, \\ Finland \\ ${ }^{\mathrm{b}}$ Finnish Forest Research Institute, Vantaa Research Unit, Vantaa, Finland
}

Correspondence:

Raija Laiho

Department of Forest Sciences, P.O. Box 27, FIN-00014 Helsinki University, Finland

Email: raija.laiho@helsinki.fi

\begin{abstract}
Changes in the structure of plant communities may have much more impact on ecosystem carbon (C) cycling than any phenotypic responses to environmental changes. We studied these impacts via the response of plant litter quality, at the level of species and community, to persistent water-level (WL) drawdown in peatlands. We studied three sites with different nutrient regimes, and water-level manipulations at two time scales. The parameters used to characterize litter quality included extractable substances, cellulose, holocellulose, composition of hemicellulose (neutral sugars, uronic acids), Klason lignin, $\mathrm{CuO}$ oxidation phenolic products, and concentrations of $\mathrm{C}$ and several nutrients.

The litters formed four chemically distinct groups: non-graminoid foliar litters, graminoids, mosses and woody litters. Direct effects of WL drawdown on litter quality at the species level were overruled by indirect effects via changes in litter type composition. The pristine conditions were characterized by Sphagnum moss and graminoid litters. Short-term (years) responses of the litter inputs to WL drawdown were small. In long-term (decades), total litter inputs increased, due to increased tree litter inputs. Simultaneously, the litter type composition and its chemical quality at the community level greatly changed. The changes that we documented will strongly affect soil properties and $\mathrm{C}$ cycle of peatlands.
\end{abstract}




\section{Introduction}

Peatlands are ecosystems accumulating organic matter due to an imbalance between net primary production and decomposition, with decomposition being slower than the production (Clymo 1984). Though the imbalance is relatively small, which in the long term translates into only $2-16 \%$ of the net primary production of a peatland ecosystem depositing as peat (Päivänen and Vasander 1994), peatlands have succeeded in storing about $30 \%$ of the global soil carbon (C) pool (Gorham 1991). With an estimated area of $3.46 \cdot 10^{6} \mathrm{~km}^{2}$ (Joosten and Clarke 2002), they constitute only about $2.3 \%$ of the Earth's land area. The C sink function of a peatland is labile, however, and sensitive to variations in environmental conditions (Bubier et al. 2003; Aurela et al. 2004, 2007; Roulet et al. 2007; Chivers et al. 2009).

Drastic changes in peatland functions may follow from land use change, and/or changes in the climate. In both cases, drawdown of the water level (WL) may be a major effect launching several other factors (Gitay et al. 2001). Water level affects several key ecosystem characteristics in peatlands, including vegetation composition (Laine et al. 1995; Talbot et al. 2010) and decomposition rates (Belyea 1996). Changes in WL may thus affect the C cycle in several ways, in part via vegetation composition and litter quality and decomposability (Laiho 2006). With respect to vegetation, a persistent change in the WL induces acclimation and adaptation, first within the existing community as changes in root:shoot ratios and species abundances (Weltzin et al. 2000; Weltzin et al. 2003), followed by slower but more drastic changes in vegetation composition when species better adapted to the new conditions gain dominance (Laine et al. 1995; Hájek et al. 2009). Changes in both species abundances and species composition may be critical turning points for the C balance of a site (e.g., Malmer et al. 2003). Litter quality is the key, for it determines the quality of the substrate as a source of energy and nutrients for decomposer microorganisms, and furthermore, different litter materials may have vastly differing rates of decomposition (Hobbie 1996; Thormann et al. 2001; Cornwell et al. 2008).

A persistent WL drawdown may directly affect litter quality, e.g. lead to changed nutrient concentrations because of changes in nutrient availability or root functioning. However, any direct effects may be overruled by the indirect effects through changes in vegetation composition (Dorrepaal et al. 2005). These effects have not been thoroughly evaluated. Shifts in vegetation composition, particularly in terms of the dominant plant functional types or growth forms, may result in overall shifts in litter quality and decomposability (Hobbie et al. 2000; Saleska et al. 2002; Quested et al. 2003). Potential shifts in the dominant plant species have been recognized as one of the key uncertainties in predictions of the $\mathrm{C}$ cycle under changing climate, because of the feedbacks through numerous mechanisms including decomposition rate (Cornelissen et al. 2007; Suding et al. 2008).

The concept of litter quality may be approached in different ways. With respect to decomposition, litter quality can simply be defined as the relative easiness/difficulty of litter decomposition by microorganisms. Litter type (plant species and organ), as such, already tells a lot about the potential decomposability (Dorrepaal et al. 2005). Parameters used in decomposition models currently include extractives (hot water and dichloromethane), cellulose, hemicellulose and lignin (Parton et al. 1987; Rastetter et al. 1991; Moorhead and Reynolds 1991; Currie and Aber 1997; Liski et al. 2005), or N/lignin ratios (Edmonds 1987; Blair 1988; Stohlgren 1988). No consensus has been reached concerning the "best" litter quality 
parameters to describe decomposability in peatlands. It is quite possible that these actually vary between litter types or plant growth forms (Thormann et al. 2001; Bragazza et al. 2007).

For estimating $\mathrm{C}$ pools and fluxes, litter input, i.e. amount of litter produced per specific time period and area, is another crucial factor. At the community level, litterfall consists of inputs of several litter types. Overall litter quality at the community level may be defined as a function of the litter quality of individual litter types and their relative inputs (Dukes and Hungate 2002; Finzi and Schlesinger 2002). Changes in relative inputs of different litter types in response to global changes may have the greatest effect on the overall litter quality in various ecosystems, including peatlands (Dorrepaal et al. 2005; Kemp et al. 1994; Weatherly et al. 2003; Henry et al. 2005).

Estimations of the $\mathrm{C}$ sink behaviour of peatlands under varying climatic conditions is based on models operating at different scales, from ecosystem-level (e.g., Frolking et al. 2002; Bauer 2004) to dynamic global vegetation models (Wania et al. 2009). The models cannot, as a rule, include vegetation at the level of plant species, partly due to computational limits, partly for increased generality, but they typically use plant growth forms or, emphasizing functional differences among species groups, plant functional types (PFTs; Box 1996). The existing models apply varying levels of species groupings the applicability of which have not been rigorously analyzed yet from the point of view of litter quality and decomposability.

The aim of this study was to determine the quality (chemical composition) of litter types typical of boreal peatland sites with varying nutrient and WL regimes. Further, we aimed to examine the effects of WL drawdown on litter quality at the species and community level, and to discuss a possible role of such effects on the peatland $\mathrm{C}$ cycle. The quality parameters analysed were selected to divide the litter into organic chemical fractions that are considered to decompose at different rates (Berg et al. 1982) and to include parameters potentially regulating the decomposition rates (Szumigalski and Bayley, 1996; Sariyildiz and Anderson, 2003; Turetsky et al. 2008). This information will be useful for estimating changes in ecosystem structure and function, including $\mathrm{C}$ cycling, and for parameterizing decomposition models for peatlands.

We hypothesized that (1) litter quality varies systematically between different litter types and (2) within the same litter type litter quality varies between sites of different nutrient and WL regimes. Further, we hypothesized that (3) litter inputs, (4) total inputs of the litter quality parameters (depending on the quality of each litter type and its input) and (5) the overall litter quality at the community level vary between sites of different nutrient and WL regimes due to differences in vegetation community structure and the overall litter quality change following WL drawdown is greater than changes within litter types.

Based on earlier results on vegetation composition (e.g., Laine et al. 1995), we expected the changes to be more pronounced after long-term (decades) relative to short-term (years) WL drawdown, and in nutrient-rich than nutrient-poor sites, due to more dramatic changes in vegetation community structure (Laine et al. 1995; Laine and Vanha-Majamaa 1992).

The research was carried out at three sites that represent typical boreal peatland types with different nutrient regime levels: bog (ombrotrophic, i.e. fed solely by precipitation; nutrient-poor), oligotrophic fen (minerotrophic, i.e. additionally fed by groundwater inputs; moderate nutrient regime), and mesotrophic fen 
(minerotrophic; nutrient-rich). We focused on above-ground litter (including mosses) because of the practical difficulties in recognizing and extracting true root litter. We expected that the patterns related to vegetation changes would emerge well enough from such material, even though we recognize the great significance of below-ground inputs (Wallén 1986, 1992; Saarinen 1996).

\section{Material and methods}

\section{Study sites}

Our study site was Lakkasuo, an eccentric raised bog complex in Central Finland $\left(61^{\circ} 48^{\prime} \mathrm{N}, 24^{\circ} 19^{\prime} \mathrm{E}\right.$, ca. $150 \mathrm{~m}$.a.s.l.). Annual rainfall in this area is $710 \mathrm{~mm}$, of which about one-third falls as snow. The average annual temperature sum (threshold value $5^{\circ} \mathrm{C}$ ) is 1160 degree days and average temperatures for January and July are -8.9 and $15.3^{\circ} \mathrm{C}$, respectively (Finnish Meteorological Institute, Juupajoki weather station 1961-1990).

Our study sites, ombrotrophic bog (OM), oligotrophic fen (OL) and mesotrophic fen (ME), included a pristine control plot (PR), a plot with short-term, ca 4 years, water level drawdown (STD), and a plot with long-term, ca 40 years, water level drawdown (LTD) (Laine et al. 2004). The PR and LTD plots sized about $900 \mathrm{~m}^{2}$. Plot sizes were selected to be well inside the chosen vegetation type, and in the immediate vicinity of the new STD plots. The size of the STD plots, demarcated by the new shallow ditches, was about $500 \mathrm{~m}^{2}$.

Within each specific site, all plots supported the same plant community and had similar soil composition and structure before disturbance. Together, these plots formed a gradient from a wet pristine peatland to a drying system and finally towards a peatland forest ecosystem (Laiho et al. 2003) at three nutrient regime levels. The PR and STD plots at the OM site included microtopographic variation typical of the site type: hummock, lawn-level and hollow microforms, each with characteristic vegetation. In the LTD plot, such variation could not be recognized any more.

The water levels in the manipulated plots were lowered by ditching. The shortterm WL drawdown had led to the average WL being 10 (bog) to 20 (fen) $\mathrm{cm}$ deeper than in the corresponding pristine plots, which is close to the estimate given by Roulet et al. (1992) for the short-term impact of climate change on WL in northern peatlands. In the LTD plots, the average WL was 15 (bog) to 40 (fen) $\mathrm{cm}$ deeper than in the pristine plots. We assume that the initial post-drainage drop in water level was close to that observed in our STD plots, and that the further lowering was caused by increased evapotranspiration by the tree stands.

In the ME site, the field layer of the PR plot was generally characterized by sedges (Carex rostrata, C. lasiocarpa) and some herbaceous species (e.g. Potentilla palustris and Menyanthes trifoliata). The moss layer consisted of Sphagnum fallax, $S$. flexuosum, S. magellanicum, S. subsecundum and Warnstorfia exannulata. The OL site was characterized by C. lasiocarpa with some Betula nana in the field layer, and $S$. papillosum, $S$. fallax and $S$. flexuosum in the moss layer. In the OM site, Eriophorum vaginatum, Andromeda polifolia and Rubus chamaemorus were the most abundant field layer species; $S$. cuspidatum was dominant in the moss layer of the hollows, $S$. balticum in the lawns and S. fuscum in the hummocks.

On the STD plots in the ME and OL sites, sedges had suffered while shrubs had flourished together with pine (Pinus sylvestris) and birch (Betula pubescens): 
seedlings of these trees were especially abundant on the STD plot of the ME site. The Sphagnum carpets showed signs of increased desiccation but had not decreased in cover. In the OM site, the changes in vegetation were small: most obviously, $S$. cuspidatum had decreased in cover and vitality.

On the LTD plots, vegetation had changed dramatically. Tree stands had become dense, and consisted of pine in the OM site, and pine with a mixture of birch and spruce (Picea abies) in the ME and OL sites. Shrubs characterized the field layer in all sites, being most notable at the OM site. E. vaginatum was practically the only surviving graminoid. Moss layers consisted of Pleurozium schreberii, $S$. angustifolium, $S$. russowii and $S$. magellanicum, with some $S$. fuscum on the OM LTD plot. On the OL and, especially, ME LTD plots, surfaces of mostly birch litter (i.e. no mosses) were also present.

In addition to vegetation composition, several soil properties had been affected by the water level drawdown (Table 1).

\section{Litter quality}

For the determination of litter quality, above-ground vascular plant litter was collected by harvesting senescent leaves and needles from living plants, and moss litter by cutting a 3-5 cm thick litter layer beyond the living shoot tips with scissors (thus, excluding both the upper green and the lower, already decomposing layers). The collected litter was further sorted and any green or visually decomposing parts of the litter were removed. Sampling took place in September and October 2004 or 2005 during the highest natural litterfall at our sites. Each litter type was air-dried at room temperature $\left(20{ }^{\circ} \mathrm{C}\right)$ to constant mass $(92-94 \%$ dry mass) and gently homogenized. For a list of litter types collected, see App. 1.

The litter quality parameters measured were extractable substances (dichloromethane- (NPE), acetone- (AE), ethanol- (EE) and water solubles (WE)), cellulose, holocellulose (sum of cellulose and hemicelluloses), composition of hemicelluloses and uronic acids (glucose, xylose, mannose, galactose, rhamnose, arabinose, galacturonic acid, glucuronic acid), lignin, $\mathrm{CuO}$ oxidation phenolic products (p-coumaric acid (C1), ferulic acid (C2), 4-hydroxybenzaldehyde (P1), 4hydroxyacetophenone (P2), 4-hydroxybenzoic acid (P3), syringe aldehyde (S1), acetosyringone (S2), syringic acid (S3), vanillin (V1), vanillic acid (V2), acetovanillone (V3)) that derive from lignin, and concentration of carbon (C), nitrogen $(\mathrm{N})$, phosphorus $(\mathrm{P})$, potassium $(\mathrm{K})$, magnesium $(\mathrm{Mg})$, manganese $(\mathrm{Mn})$ and calcium $(\mathrm{Ca})$.

The amounts of extractable substances were determined gravimetrically by sonicating milled samples with a solvent in a sonicator water bath and weighing the samples after filtration and drying. Mass loss during each extraction was considered to be the content of extractable compounds. Dichloromethane was used to remove nonpolar extractives (e.g. fats, oils, resins, waxes, plant pigments, fatty alcohols, fatty acids) and acetone, ethanol and hot water to remove polar extractives (e.g. soluble carbohydrates, ketones, pectins, tannins). Basics of these analyses may be found in Ryan et al. (1990) and Wieder and Starr (1998).

Extractive-free samples were then hydrolysed in sulphuric acid. Primary hydrolysis of each $0.3 \mathrm{~g}$ sample was performed with $1.00 \mathrm{ml} 72 \% \mathrm{H}_{2} \mathrm{SO}_{4}$ for $1 \mathrm{~h}$ in a sonicator bath at $30{ }^{\circ} \mathrm{C}$. Hydrolysates were then diluted to $4 \% \mathrm{H}_{2} \mathrm{SO}_{4}$ by ultrapure water and a secondary hydrolysis was performed for $1 \mathrm{~h}$ at $120{ }^{\circ} \mathrm{C}$ and pressure 1.2 bar. The non-hydrolysable residue was defined as Klason lignin after filtration and 
drying. The filtrates (hydrolysates) from the Klason lignin determination were diluted by ultrapure water (at such a rate that the following absorbance readings would fall between 0.2 and 0.7 , the rate of dilution varied between litter types) and absorption of the solutions was measured at $203 \mathrm{~nm}$ with Shimadzu UV-2401 PC UV-VIS Recording Spectrophotometer, using the 1-cm light path cuvette. Sulphuric acid of the same concentration as in the samples was used as a reference blank. The percentage of acid soluble lignin was calculated according to Ehrman (1996). An absorptivity (extinction coefficient) value of $110 \mathrm{~L} / \mathrm{g}-\mathrm{cm}$ was used in the calculation. This value was suitable for woody samples (Ehrman 1996; TAPPI Official Method T222 om-88 for the Determination of Acid-soluble Lignin in Wood and Pulp) but may not be optimal for the other litter types. To get information about the composition of the lignin fraction, the modified degradative alkaline $\mathrm{CuO}$ oxidation method was used (Hedges and Ertel 1982). Mosses do not contain lignin, but they contain phenolics and other components that the methods we used for soluble and Klason lignin determination may capture.

Holocellulose (sum of cellulose and hemicelluloses) was determined from extractive-free samples using the sodium chlorite method (Quarmby and Allen 1989). The amounts of neutral and acidic sugar units in non-cellulosic polysaccharides were obtained by acid methanolysis followed by gas chromatography (GC), using a modified method of Sundberg et al. (1996). The amount of cellulose was determined by GC after acid hydrolysis and silylation according to Sundberg et al. (2003). The amount of glucose units determined by acid methanolysis and GC, i.e. glucose present in hemicelluloses, was subtracted from the amount determined by the acid hydrolysis.

Concentrations of $\mathrm{C}$ and $\mathrm{N}$ were determined from air-dried samples with a LECO CHN-1000 analyzer, and the concentrations of other elements with an ICP emission spectrometer (ARL 3580) after dry ashing and dissolution of the ash with hydrochloric acid $(\mathrm{HCl})$. Dry mass content was determined by drying subsamples at $105^{\circ} \mathrm{C}$ overnight and the ash content by combustion at $550^{\circ} \mathrm{C}$ for $4 \mathrm{~h}$.

The mean values of the measured properties per litter type are shown in App. 1.

\section{Litter production}

Twelve sampling points were placed on each plot in May 2005, except in the ME STD plot on which it was possible to find space only for six. On the PR and LTD plots, the points were placed systematically in two or three lines, four meters apart from one another. If the sampling point fell on some obstacle, it was moved half a meter along the line. Space was limited in the STD plots on all the sites and therefore the sampling point placement was arbitrary. However, care was taken to ensure that all different vegetation types were included. A litter collector was placed at each sampling point, and a spot for measuring moss growth was marked half a meter away from the point along the line.

Since we wanted to quantify the inputs from all vegetation layers, we could not apply the "standard" collectors (Graca et al. 2005). Instead, we used either $30 \mathrm{~cm}$ x $30 \mathrm{~cm}$ wooden frames or bendable wire frames, both with a $6 \mathrm{~mm}$ x $6 \mathrm{~mm}$ polyester mesh attached to them. First, any fresh litters were cleared from the locations. The collectors were placed so that all the vegetation was carefully lifted through the mesh and the mesh was lying neatly right on top of the soil or moss surface. Larger holes were made in the mesh if needed for bigger shrubs. The wooden frames were used on level surfaces and the wire frames were used in places where wooden frames were not applicable, e.g. at spots with dense shrub vegetation. The wire frames were bent in a way that they could be set horizontally on the surface. The area of these frames was 
estimated from photographs using Arc-GIS. Since the collectors were lying tightly on the surface, it was easy to note and pick also the litters that were partly sticking through the mesh. Only the very smallest litters, such as Empetrum nigrum leaves, would be underestimated by this method, and their mass proportions would have been negligible in any case.

The litter was collected from the mesh on four occasions from September to October 2005. Only the amount of litter input to the soil surface was measured. All the dead graminoids were collected at the end of October, however, for it was assumed that the snow cover would push them into the soil surface. The litter was sorted by plant species and, when applicable, by plant organ (foliage, twigs and branches, bark, cones etc.). All samples were dried at $105^{\circ} \mathrm{C}$ to constant mass and weighed.

Concerning mosses, an assumption was made that the growth of a moss shoot from the apical tip is the same as the dying of the shoot from the other end, and therefore the biomass production and the litter production are the same. This was done because with several species measuring the growth is easier than measuring the actual litter production. The applicability of the assumption was tested by comparing the growth and the litter production in species with which the latter could be easily measured.

The growth of mosses was measured using a method developed by Ilomets (1974). A handful of mosses was picked up, carefully sorted by species, and 15 of each were marked with white nitrocellulose paint on the shoot $2.0 \mathrm{~cm}$ below the apical tip. On suitable species another mark was painted on the limit between the living and the dead part of the shoot. After marking, the mosses were carefully placed back on the spot from which they had been taken. Polytrichum commune shoots were marked without picking them up. The marking was done from May to early June 2005. The marked mosses were picked up in mid-October. By this time it was often impossible to recognize the marked spots from the undisturbed moss surface, and thus we concluded that the method would lead to reliable estimates. In some spots, the samples were actually not found; average growth values of the species in question were applied in such cases.

The moss samples were then sorted according to species. The parts of the shoots that were between the painted marks ("old" $2-\mathrm{cm}$ point) and the points $2 \mathrm{~cm}$ below the tips at the time of pick-up were cut off. This was the amount the moss shoots can be considered to have grown after marking. If the mosses had branched above the marks, the new branches were wholly included in the production estimates. The samples were dried in $105^{\circ} \mathrm{C}$ and weighed. The mass produced by each species was divided by the number of the shoots measured for that species to obtain average production per shoot. The result was transformed to an area-based estimate using the numbers of shoots for each species counted from $21.65 \mathrm{~cm}^{2}$ circular samples taken from spots adjacent to the marked mosses. In some points, the marked samples did not contain all the species present in the per unit area sample. In these cases, an estimate based on average production for that species from similar sampling points was used.

\section{Statistical analyses}

Variation in litter quality between different litter types (plant species and organ; Hypothesis 1) was explored by principal component analysis (PCA), using the measured litter quality parameters as response variables, and binary variables describing litter types and sites as (passive) explanatory variables. The grouping of different litter types based on their quality was verified by cluster analysis that was 
conducted using Euclidean distance for dissimilarity measures and Ward's clustering method.

To estimate the effects of site and drainage on litter inputs (Hypothesis 3), variation partitioning was performed by canonical correspondence analysis (CCA). Measured inputs of different litter types were used as response variables, and a group of binary variables describing either site or drainage was kept at a time as explanatory variables while the other group was used as covariables.

To estimate the effects of site and drainage on litter quality, variation partitioning was performed by redundancy analysis (RDA) with explanatory variables and covariables as described above for CCA. Four different tests were performed. (a) To estimate these effects on given litter type (Hypothesis 2), quality parameters of only the litter types which were present at all nine plots were used as response variables. These included pine needles, pine cones, pine branches of two diameter classes (diameter $\leq 1 \mathrm{~cm}$ and $1-2 \mathrm{~cm}$ ), Betula nana leaves, Eriophorum vaginatum leaves, E.vaginatum basal sheaths and Sphagnum angustifolium, and are henceforward called common litters. In this test, the effect of litter type (binary variables) and the combined effect of site and drainage were also estimated. (b) To estimate the effects of site and drainage on the total inputs of the litter quality parameters (Hypothesis 4), parameters measured for each litter type were weighed by the input of the litter type and used as response variables. Binary variables describing either site or drainage were again applied as explanatory variables and covariables. (c) To estimate these effects on the inputs of individual litter quality parameters, response variables were defined as for (b) but separate tests were performed for each litter quality parameter (d) To test how the overall litter quality at the community level varies between sites of different nutrient and WL regimes (Hypothesis 5), response variables were defined as for (b) and standardized per sample to convert the absolute values to the relative ones.

The choice of test (linear (PCA, RDA) or unimodal (CCA) response model) was based on the heterogeneity of the response variable data, i.e. the extent of response variable turnover, in each case. This was evaluated using detrended correspondence analysis (DCA) (Leps and Smilauer 2003). The ordinations were performed using Canoco for Windows version 4.5 (ter Braak and Smilauer 2002), and the cluster analysis using Statistica for Windows version 6.1 (StatSoft, 2003). Standardized values of litter quality parameters were used in all analyses to eliminate the scale effect.

\section{Results}

\section{Variation in litter quality between the litter types}

We identified three main gradients in litter quality, described below. Four different groups of litter were clearly distinguished along these gradients: nongraminoid foliar litters, graminoids, mosses and woody litters. Further analyses at the group level revealed some interesting patterns within these groups.

Non-graminoid foliar and moss litters differed from woody and graminoid litters along the strongest gradient (Fig. 1, Axis 1), which accounted for $29.3 \%$ of the total variation in litter quality. $\mathrm{K}, \mathrm{P}, \mathrm{Mg}$, galacturonic acid, rhamnose, soluble lignin (high in non-graminoid foliar litters and/or mosses) and V1 (high in woody and graminoid litters) defined this gradient. Non-graminoid foliar litters were separated from mosses along the second strongest gradient (Axis 2), which comprised $22.3 \%$ of 
the total variation; $\mathrm{C}, \mathrm{Ca}, \mathrm{AE}, \mathrm{EE}, \mathrm{WE}$ (high in non-graminoid foliar litters), galactose, holocellulose, P1, P2 (high in mosses) defined this gradient. Graminoids were separated from the other litter types along the third gradient (Axis 3), which represented $18.2 \%$ of the total variation; $\mathrm{C} 1, \mathrm{C} 2, \mathrm{~S} 1, \mathrm{~S} 2$ and xylose defined this gradient. Same patterns can be seen in a tree diagram of cluster analysis (App 2).

Generally, non-graminoid foliar litters had a high content of nutrients and extractives (Fig. 1, App 1). Pine needle litter contained a higher concentration of nonpolar extractives and a lower concentration of nutrients compared to the other nongraminoid foliar litters. Sphagnum mosses were rich in rhamnose, galactose, glucose, glucuronic acid, galacturonic acid, soluble lignin, P1, P2 and P3. Pleurozium schreberi differed from the Sphagnum mosses by having a higher Klason lignin and mannose concentration, and lower concentration of the aforementioned compounds typical of Sphagna, but it was still closer to these mosses than to other litter types. Hummock Sphagnum species (S. russowii, S. magellanicum, S. fuscum; S. papillosum grouped with these species) displayed a higher content of cellulose and lignin-like compounds (Klason lignin, $\mathrm{CuO}$ oxidation phenolic products) and lower content of hemicellulose than the lawn-level and hollow species ( $S$. fallax, S. balticum, $S$. cuspidatum; S. angustifolium grouped with these species) (Fig. 2). Woody litters were marked by a high Klason lignin content. Pine woody litters (high mannose, V1, V2 and V3 content) differed from birch woody litters (high S1, S2 and S3 content). Graminoids were characterized by a high arabinose, xylose, S1, S2, S3, C1 and C2 concentration; additionally, E. vaginatum basal sheaths evinced a high V1, V2 and V3 content.

\section{Effect of site and drainage}

Both site and drainage had a significant effect on litter quality at the species (litter type) level (Table 2, common litters) even though the effects were minor compared to the variation between litter types. Litters from the STD (short-term drainage) plots at the fen sites showed a tendency of higher $\mathrm{N}$ and lower glucose contents, litters from all LTD (long-term drainage) plots a tendency of higher $\mathrm{P}$ content. The combined effect of site and drainage was also only $2.3 \%$.

Both site and drainage had a significant effect on litter inputs (Table 2). The clearest effect was an increase in tree litters (leaves, needles, branches, cones) following LTD, which also led to an overall increase in the inputs (Fig. 3). At the fen sites, graminoid litter inputs that mainly consisted of Carex species were reduced after STD, and were minor or non-existent following LTD. At the bog site, graminoid litter consisted of Eriophorum vaginatum and the inputs did not change following drainage. Inputs of herbaceous litter increased following drainage at the bog site where it mainly consisted of Rubus chamaemorus, while at the fen sites there were no clear patterns. Sphagnum moss litter was typical of the PR and STD plots, whereas inputs from other moss species, mostly $P$. schreberi, increased after LTD.

Following changes in litter inputs (Fig. 3), the inputs of all litter quality parameters increased dramatically after LTD (Table 2; examples in Fig. 5). Site had no effect, even though there were several site-specific litter types. When looking at the individual quality parameters (Fig. 5), some patterns could be seen but they varied between parameters and thus yielded a nonsignificant overall effect. The effect of drainage on the single quality parameters varied between $27 \%$ and $45 \%$, and the effect of site between $3.5 \%$ and $7 \%$ for the parameters shown in Fig 5; the bog site (OM) differed somewhat from the fen sites (ME and OL). At the fen sites, a change in the inputs of litter quality parameters occurred already after STD (via lowered sedge and 
Sphagnum litter inputs and increased inputs of tree litters), while at the bog site it appeared only after LTD (Fig. 4). Pine needles, pine branches, B. pubescens leaves and $P$. schreberi greatly contributed to the high amount of extractives, nutrients and lignin produced at the LTD plots.

Both site and drainage had a significant effect on the overall litter quality at the community level (Table 2). Litter produced at the LTD plots had a higher proportion of Klason lignin, V1, V2 and V3 (typical for woody litters), extractives (typical for non-graminoid foliar litters), mannose (typical of woody litters, $P$. schreberi and pine needles), $\mathrm{P}$ (typical of B. pubescens and Vaccinium uliginosum leaves, and also some mosses growing at LTD plots: P. schreberi, S. magellanicum), $\mathrm{C}$ and cellulose compared to the PR and STD plots (Fig. 6a). Again, at the fen sites a change took place in the overall litter quality at the community level already after STD, while at the bog site it appeared only after LTD (Fig. 6b).

\section{Discussion}

\section{Variation in litter quality among litter types}

Relatively clear grouping into growth forms (mosses, non-graminoid foliar litters, woody litters, graminoids) was found among the different litter types, based on their chemical composition. It is interesting that the graminoids were closer to woody litters than to the non-graminoid foliar litters. Non-graminoid foliar litters were rich in nutrients and extractives, and woody litters had a high Klason lignin content, in line with other studies (e.g., Scowcroft 1997; Dorrepaal et al. 2005; Bragazza et al. 2007). Nutrients (mainly $\mathrm{N}$ and $\mathrm{P}$ ) and easily extractable compounds are generally associated with high early decomposition rates in vascular plant litters (McClaugherty et al. 1985; Taylor et al. 1989; Berg and Ekbohm 1991; Tian et al. 1992). Lignin, C:N, lignin:N and C:P, in turn, have negative correlation with mass loss (Taylor et al. 1991; Aerts and De Caluwe 1997; Moore et al. 1999) and N may also slow down decomposition in its later stages (Berg et al. 1982; Fog 1988; Saiya-Cork et al. 2002).

Sphagnum species were characterized by a relatively high content of $\mathrm{p}$ hydroxyl phenols ( $\mathrm{CuO}$ oxidation phenolic products) and other components that were captured as a soluble lignin and Klason lignin fraction. The existence of a polyphenolic network composed of p-hydroxyphenyl groups in Sphagnum mosses has already been demonstrated (Wilson et al. 1989; Rasmussen et al. 1995; Williams et al. 1998); p-hydroxyl phenols may have both lignin and nonlignin sources (Williams et al. 1998). Within the group of Sphagnum mosses, species of sections Acutifolia and Sphagnum (S. fuscum, S. russowii, S. magellanicum, S. papillosum; typical of hummocks and/or lawns) had a higher cellulose content compared to the ones of section Cuspidata (S. angustifolium, S. fallax, S. balticum, S. cuspidatum; typical of hollows and/or lawns) which contained a high level of hemicellulose. This separation was interesting since generally, it has been observed that hummock species decompose at slower rates than hollow species (Johnson and Damman 1991; Limpens and Berendse 2003). Cellulose degradation starts somewhat later than the degradation of hemicellulose (Berg and McClaugherty 2003) and thus, the higher cellulose:hemicellulose ratio may be associated with slower decomposition of the hummock Sphagnum species, besides the effect of Klason lignin and polyphenols that were also higher in content in them. Similarly, Turetsky et al (2008) found that the higher structural:metabolic carbohydrates ratio of hummock Sphagnum species was associated with their slower decomposition rates. 
The effect of hemicellulose composition on the decomposition process is potentially interesting but has not been fully studied yet. Berg and McClaugherty (2003) reported that in pine needle litter arabinose and galactose start to decompose immediately after litterfall, while mannose and xylose after more than one year. We found a strong variation in hemicellulose composition between the different growth forms, which is in line with some other studies (Berg and Ekbohm 1991; Eriksson et al. 1990; Comont et al. 2006). As the different units comprising hemicellulose often correlated with each other or with other litter quality parameters we cannot discuss the possible effect of hemicellulose composition on the decomposability based on the litter quality data alone.

Previous studies have shown that growth form predicts to some extent the variation in decomposability. Generally, woody litters and mosses decompose slowly, and needle litters decompose more slowly than deciduous, forb and graminoid leaf litters (Hobbie 1996; Hobbie et al. 2000; Preston et al. 2000; Dorrepaal et al. 2005; Bragazza et al. 2007). However, within these simplified growth form categories, there is also such variation in litter quality that affects the decomposition rates (Bragazza et al. 2007; Turetsky et al. 2008). Also, there is some evidence that the decomposer community may vary significantly within litters from a single growth form, based on the variation in the chemical quality (K. Peltoniemi et al., unpublished data). Our extensive data on the chemical quality of different litter types may be used for evaluating variation in decomposability between and within growth forms, and parameterizing decomposition models for a number of litter types. This information is crucial for estimating $\mathrm{C}$ dynamics in peatlands under changing conditions.

\section{Direct effects of water level drawdown overruled by the indirect ones}

Our results indicated that both site nutrient and water level regimes had a significant direct effect on litter quality. However, no clear inter-regime patterns emerged, and the impacts were minor compared to the indirect effect via changes in litter type composition. The litter quality greatly changed at the ecosystem level, through a relative increase in tree litter inputs following a long-term WL drawdown. This supports the postulate of Dorrepaal et al. (2005) that the direct effects of environmental changes on litter quality may be overruled by the indirect effects via changes in the relative abundance of growth forms. It also corresponds to the finding of Aerts et al. (2009) that climate manipulation effects on species-level leaf nutrient and carbon exchange variables of several bog species were small compared to interspecific differences. Together, these results provide strong evidence that changes in the species composition and structure of plant communities will have much more impact on plant-mediated carbon cycling in peatlands than climate-change induced phenotypic responses. It is noteworthy that the short-term and long-term effects were very different in our study. The short-term changes reflect transient conditions, while the long-term changes reflect a longer-lasting situation as the ecosystem becomes adapted to the new conditions. So far, too few studies have considered the long-term aspect.

\section{Long-term changes in litter inputs are dramatic}

The effect of WL drawdown on litter inputs had several common patterns at sites with different nutrient regimes. Sphagnum mosses that produce litter with low decomposability (Hobbie et al. 2000; Dorrepaal et al. 2005; Cornelissen et al. 2007) were typical in pristine conditions and following short-term WL drawdown. Mosses other than Sphagnum species, mostly $P$. schreberii, whose litter quality did not generally differ much from that of Sphagna, increased their abundance after the long- 
term WL drawdown. Graminoid and forb litter typical of the pristine fens, especially, was continuously replaced by shrub, and finally tree litter. Following the long-term WL drawdown, all the peatland sites were transformed to produce high amounts of litter, the origin of which greatly differed from the litter produced in pristine conditions or after short-term WL drawdown. Persistent WL drawdown has a clear positive feedback on decomposition through increased aeration of the soil profile (Lähde 1969; Boggie 1977; Silins and Rothwell 1999). However, a negative feedback may result from the shifts in vegetation composition and litter quality. Due to the drastically increased tree litter inputs, high amounts of litter with high lignin content, $\mathrm{C}: \mathrm{N}$, lignin: $\mathrm{N}, \mathrm{C}: \mathrm{P}$ and potentially low decomposability (woody litter) as well as litter with high nutrient content and easily extractable compounds and thus potentially high decomposability (birch leaves, needles) were produced at the LTD plots. Overall, it seems that the litter produced at the LTD plots has a lower decomposability than litter produced at the pristine plots.

\section{Implications for soil C}

Two main implications may be drawn from our results. First, after short-term water-level drawdown improved conditions for aerobic decomposition are linked with unchanged or lowered amounts of organic matter inputs, most likely facilitating a net $\mathrm{C}$ loss from the soil. In contrast, in the long-term, the increased litter inputs may at least partly compensate for the increased rates of decomposition in the soil. Such a pattern has actually been demonstrated by Hargreaves et al. (2003) in artificially afforested Scottish peatland sites. Second, the changes in litter type composition that we documented will eventually result in a 2-layer, or 2-compartment, structure in the oxic surface peat; atop the "old peat" layer consisting of a continuum of decomposition products from the pre-WL drawdown litter types, a layer of the "new litter" will be introduced (see also Laiho 2006). The two layers or compartments may be very different, as shown by the litter quality data. The old peat compartment may only decompose, while the new compartment is a dynamic system where both inputs and decomposition take place. As a consequence, interpretation of $\mathrm{CO}_{2}$-exchange studies gets more complicated. Only few studies separated gas fluxes from decomposing peat and decomposing fresh litter (Minkkinen et al. 2007; Jaatinen et al. 2008; Mäkiranta et al. 2008). The increase in the rate of decomposition of the old peat may be a more critical parameter than the $\mathrm{C}$ exchange of the litter layer that may, however, have a major contribution to the net $\mathrm{CO}_{2}$ efflux (Laiho et al. 2008) and will mask any changes in the soil $\mathrm{C}$ balance unless the quantity of the litter inputs is known and accounted for.

Overall, the role of the changing vegetation in the $\mathrm{C}$ cycling following a persistent lowering of the water level has been largely neglected in previous research. Changes in vegetation community composition may affect the decomposition process in several ways: via shifts in litter types and their chemical quality as outlined here, but also via interactions (either positive or negative) between different litter types when decomposing as mixtures (Gartner and Cardon 2004), and via the specific conditions and decomposer communities that develop under certain vegetation (e.g., Nilsson et al. 2008; Laganière et al. 2010). Since the vegetation of fens and bogs responds differently to WL drawdown it is likely that the implications to soil functioning will also differ.

Our study included only above-ground litter. However, we expect that the changes in the amount and species composition of below-ground litter inputs will follow a similar pattern as for above-ground litter. Roots of herbs and graminoids are largely replaced by roots of trees and shrubs following a persistent WL drawdown 
(Laiho et al. 2003; Murphy et al. 2009). Data from our bog site indicate that fine root production, and thus probably litter formation as well, may be of similar magnitude in both the pristine and long-term drained plots (Murphy et al. 2009). In the fen sites, a decline in fine root production may be more likely (Laiho et al. 2003).

\section{Implications for soil C modelling}

Our results suggest that the shift in vegetation composition as a response to land-use and/or climate change is the main factor affecting the peatland ecosystem $\mathrm{C}$ cycle. Thus, dynamic vegetation is a necessity in any models applied for estimating responses of $\mathrm{C}$ fluxes to changes in environmental conditions. It is noteworthy that the time scale for vegetation changes caused by hydrological changes needs to extend to decades. When litter quality is considered, certain plant functional types (PFT) are distinct; however, plant part or tissue type also plays a role since, e.g., woody and foliar litters of trees and shrubs essentially differ from each other. Different species aggregation levels are needed for models operating at different scales, and possibly when accounting for different $\mathrm{C}$ cycling processes (Dorrepaal 2007). At the very least, distinction between non-graminoid foliar litters (including all arboreal plants and herbs), graminoids, mosses, and woody litters should be made based on litter quality (App. 2). When more detail may be applied, we suggest the PFT and litter type distinction presented in Table 3. Pine cones would be chemically distinct enough to merit separation but we have included them in "woody litter" for purely pragmatic reasons. Root litters should possibly be considered separately but we have no data for those. The only herb species in our material was Rubus chamaemorus that grows even in ombrotrophic sites; minerotrophic herbs might show more difference to other litter types. Of the existing models, the dynamic global vegetation model LPJ-Why (Wania et al. 2009), and the ecosystem-level models by Zhang et al. (2002) and Bauer (2004) cover the minimum requirement of PFT and/or litter type separation quite well. However, model development for simulating plant community level successional dynamics of ecohydrology-vegetation interactions could benefit from our more detailed plant litter characterizations.

\section{Will ditching and climate change lead to similar responses?}

Water level as such is an important regulator of peatland vegetation. Changes in precipitation and temperature patterns have already been documented to have led to increased shrub and tree coverage in previously wet, open peatlands (e.g., Berg et al. 2009). Increasing tree stand will further act as an ecological engineer via increasing evapotranspiration causing "biological drainage", and increasing shading.

Yet, the different mechanisms leading to water-level drawdown in man-made versus climate-induced drainage may, even if they lead to similar water-level regimes, bring about some differences in nutrient ecology that may affect vegetation dynamics and litter inputs. Water removal via ditches will carry solutes such as some nutrients away from the ecosystem (Sallantaus 1992, Prevost et al. 1999), while water removal via evapotranspiration will not lead to such losses. Further, ditching is considered to lead to functional ombrotrophy by capturing and diverting the runoff (and nutrient inflow) coming from the catchment. Where basins are steeply inclined (as in our study site Lakkasuo), groundwater influence through the peat may continue (Laine et al. 2004), but this influence is difficult to quantify and will vary among basins. On the other hand, changed precipitation and temperature patterns may also lead to altered water inputs from the catchment. Where water inputs are lowered, shortage of base cations may eventually impede tree growth on deep peat (Sallantaus 1992; Laiho et al. 2003). No adverse effects on site productivity have been found to take place at least during the first 40 years following ditching, however (Hökkä and Penttilä 1999). Yet, 
the long-term fate of initially nutrient-rich peatlands may be disputed; that of bogs affected by precipitation only is easier to predict.

\section{Acknowledgements}

This study was supported by the Academy of Finland projects 104425 and 106197. We thank Satu Repo, Tuija Hytönen, Minna Piippo and Päivi Paasela for their valuable help with the laboratory work, Timo Penttilä, Nigel Roulet and the other reviewers for helpful comments on the manuscript, Meeri Pearson for correcting the language, and Jan Květ for pre-submission review of the manuscript.

\section{References}

Aerts R, De Caluwe H (1997) Nutritional and plant-mediated controls on leaf litter decomposition of Carex species. Ecology 78:244-260

Aerts R, Callaghan TV, Dorrepaal E, van Logtestijn RSP, Cornelissen JHC (2009). Seasonal climate manipulations result in species-specific changes in leaf nutrient levels and isotopic composition in a sub-arctic bog. Functional Ecology 23:680688

Aurela M, Laurila T, Tuovinen J-P (2004) The timing of snow melt controls the annual $\mathrm{CO}_{2}$ balance in a subarctic fen. Geophysical Research Letters 31, L16119, doi:10.1029/2004GL020315

Aurela M, Riutta T, Laurila T, Tuovinen J-P, Vesala T, Tuittila E-S, Rinne J, Haapanala S, Laine $\mathrm{J}$ (2007) $\mathrm{CO}_{2}$ exchange of a sedge fen in southern Finland The impact of a drought period. Tellus B 59:826-837

Bauer IE (2004) Modelling effects of litter quality and environment on peat accumulation over different time-scales. Journal of Ecology 92:661-674

Belyea LR (1996) Separating the effects of litter quality and microenvironment on decomposition rates in a patterned peatland. Oikos 77:529-539

Berg B, Ekbohm G (1991) Litter mass-loss rates and decomposition patterns in some needle and leaf litter types. Long-term decomposition in a Scots pine forest. VII. Canadian Journal of Botany 69:1449-1456

Berg B, Hannus K, Popoff T, Theander O (1982) Changes in organic-chemical components during decomposition. Long-term decomposition in a Scots pine forest I. Canadian Journal of Botany 60:1310-1319

Berg B, McClaugherty C (2003) Plant Litter - Decomposition, Humus Formation, Carbon Sequestration. Springer Verlag, Heidelberg, Berlin, New York

Berg EE, McDonnell Hillman K, Dial R, DeRuwe A (2009) Recent woody invasion of wetlands on the Kenai Peninsula Lowlands, south-central Alaska: a major regime shift after 18000 years of wet Sphagnum-sedge peat recruitment. Canadian Journal of Forest Research 39:2033-2046

Blair JM (1988) Nitrogen, sulfur and phosphorus dynamics in decomposing deciduous leaf litter in the southern Appalachians. Soil Biology and Biochemistry 20:693-701

Boggie R (1977) Water-table depth and oxygen content of deep peat in relation to root growth of Pinus contorta. Plant and Soil 48:447-454 
Box EO (1996) Plant Functional Types and Climate at the Global Scale. Journal of Vegetation Science 7:309-320

Bragazza L, Siffi C, Iacumin P, Gerdol R (2007) Mass loss and nutrient release during litter decay in peatland: The role of microbial adaptability to litter chemistry. Soil Biology and Biochemistry 39:257-267

Bubier JL, Bhatia G, Moore TR, Roulet NT, Lafleur PM (2003) Spatial and temporal variability in growing-season net ecosystem carbon dioxide exchange at a large peatland in Ontario, Canada. Ecosystems 6:353-367

Chivers MR, Turetsky MR, Waddington JM, Harden JW, McGuire AD (2009) Effects of experimental water table and temperature manipulations on ecosystem $\mathrm{CO}_{2}$ fluxes in an Alaskan rich fen. Ecosystems 12:1329-1342

Clymo RS (1984) The limits to peat bog growth. Philosophical Transactions of the Royan Society of London, B 303:605-654

Comont L, Laggoun-Défarge F, Disnar J (2006) Evolution of organic matter indicators in response to major environmental changes: The case of a formerly cut-over peat bog (Le Russey, Jura Mountains, France). Organic Geochemistry $37: 1736-1751$

Cornelissen JH, van Bodegom PM, Aerts R, et al (2007) Global negative vegetation feedback to climate warming responses of leaf litter decomposition rates in cold biomes. Ecology Letters 10:619-627

Cornwell WK, Cornelissen JHC, Amatangelo K, et al (2008) Plant species traits are the predominant control on litter decomposition rates within biomes worldwide. Ecology Letters 11:1065-1071

Currie WS, Aber JD (1997) Modeling leaching as a decomposition process in humid, montane forests. Ecology 78:1844-1860

Dorrepaal E (2007) Are plant growth-form-based classifications useful in predicting northern ecosystem carbon cycling feedbacks to climate change? Journal of Ecology 95:1167-1180

Dorrepaal E, Cornelissen JHC, Aerts R, Wallén B, van Logtestijn RSP (2005) Are growth forms consistent predictors of leaf litter quality and decomposability across peatlands along a latitudinal gradient? Journal of Ecology 93:817-828

Dukes JS, Hungate BA (2002) Elevated carbon dioxide and litter decomposition in California annual grasslands: which mechanisms matter? Ecosystems 5:171-183

Edmonds RL (1987) Decomposition rates and nutrient dynamics in small-diameter woody litter in four forest ecosystems in Washington, U.S.A. Canadian Journal of Forest Research 17:499-509

Ehrman T (1996) Determination of acid-soluble lignin in biomass. LAP-004 1-7

Eriksson KE, Blanchette RA, Ander P (1990) Microbial and enzymatic degradation of wood and wood components. Springer Verlag, Berlin

Finzi AC, Schlesinger WH (2002) Species control variation in litter decomposition in a pine forest exposed to elevated $\mathrm{CO}_{2}$. Global Change Biology 8:1217-1229

Fog K (1988) The effect of added nitrogen on the rate of decomposition of organic matter. Biological Reviews 63:433-462 
Frolking S., Roulet NT, Moore TR, Lafleur PM, Bubier JL, Crill PM (2002)

Modeling the seasonal and annual carbon balance of Mer Bleue bog, Ontario, Canada. Global Biogeochemical Cycles 16, doi:10.1029/2001GB001457

Gartner TB, Cardon ZG (2004) Decomposition dynamics in mixed-species leaf litter. Oikos 104: 230-246

Gitay H, Brown S, Easterling W, et al (2001) Ecosystems and their goods and services. In: McCarthy JJ, Canziani OF, Leary NA, Dokken DJ, White KS (eds) Climate change 2001, impacts, adaptation, and vulnerability, Contribution of Working Group II to the Third Assessment Report of the Intergovernmental Panel on Climate Change. Cambridge University Press, Cambridge, pp 235-342

Gorham E (1991) Northern peatlands: role in the carbon cycle and probable responses to climatic warming. Ecological Applications 1:182-195

Graca MAS, Bärlocher F, Gessner MO (2005) Methods to Study Litter Decomposition: a Practical Guide. Springer, Dordrecht

Hájek T, Tuittila ES, Ilomets M, Laiho R (2009) Light responses of mire mosses - a key to survival after water-level drawdown? Oikos 118:240-250

Hargreaves KJ; Milne R; Cannell MGR (2003) Carbon balance of afforested peatland in Scotland. Forestry 76:299-31

Hedges JI, Ertel JR (1982) Characterization of lignin by capillary chromatography of cupric oxide oxidation products. Analytical Chemistry 54:174-178

Henry HAL, Cleland EE, Field CB, Vitousek PM (2005) Interactive effects of elevated $\mathrm{CO}_{2}, \mathrm{~N}$ deposition and climate change on plant litter quality in a California annual grassland. Oecologia 142:465-473

Hobbie SE (1996) Temperature and plant species control over litter decomposition in Alaskan tundra. Ecological Monographs 66:503-522

Hobbie SE, Schimel JP, Trumbore SE, Randerson JR (2000) Controls over carbon storage and turnover in high-latitude soils. Global Change Biology 6:196-210

Hökkä H, Penttilä T (1999) Modelling the dynamics of wood productivity on drained peatland sites in Finland. Silva Fennica 33:25-39.

Ilomets M (1974) Some aspects of measuring the growth of Sphagnum. In: Kumari E (ed) Estonian Wetlands and Their Life. Valgus, Tallinn, pp 191-203

Jaatinen K, Laiho R, Vuorenmaa A, del Castillo U, Minkkinen K, Pennanen T, Penttilä T, Fritze H (2008) Responses of aerobic microbial communities and soil respiration to a water-level drawdown in a northern boreal fen. Environmental Microbiology 10:339-353

Johnson LC, Damman AWH (1991) Species-controlled Sphagnum decay on a South Swedish raised bog. - Oikos 61: 234-242.

Joosten H, Clarke D (2002) Wise use of mires and peatlands: Background and principles including a framework for decision-making. International Mire Conservation Group and International Peat Society, Saarijärvi

Kemp PR, Waldecker D, Owensby CE, Reynolds JF, Virginia RA (1994) Effects of elevated $\mathrm{CO}_{2}$ and nitrogen fertilization pretreatments on decomposition of tallgrass prairie leaf litter. Plant and Soil 165:115-127 
Laganière J, Paré D, Bradley RL (2010) How does a tree species influence litter decomposition? Separating the relative contribution of litter quality, litter mixing, and forest floor conditions. Canadian Journal of Forest Research 40: $465-475$

Lähde E (1969) Biological activity in some natural and drained peat soils with special reference to oxidation-reduction conditions. Acta Forestalia Fennica 94:1-69

Laiho R (2006) Decomposition in peatlands: Reconciling seemingly contrasting results on the impacts of lowered water levels. Soil Biology and Biochemistry 38:2011-2024

Laiho R, Vasander H, Penttilä T, Laine J (2003) Dynamics of plant-mediated organic matter and nutrient cycling following water-level drawdown in boreal peatlands. Global Biogeochemical Cycles 17(2), 1053, doi:10.1029/2002GB002015

Laiho R, Minkkinen K, Anttila J, Vávřová P, Penttilä T (2008) Dynamics of litterfall and decomposition in peatland forests: Towards reliable carbon balance estimation? In: Vymazal J (ed) Wastewater treatment, plant dynamics and management in constructed and natural wetlands. Springer Science + Business Media, Dordrecht, pp 53-64

Laine J, Vanha-Majamaa I (1992) Vegetation ecology along a trophic gradient on drained pine mires in southern Finland. Annales Botanici Fennici 29:213-233

Laine J, Vasander H, Laiho R (1995) Long-term effects of water level drawdown on the vegetation of drained pine mires in southern Finland. Journal of Applied Ecology 32:785-802

Laine J, Komulainen VM, Laiho R, et al (2004) Lakkasuo - a guide to mire ecosystem. University of Helsinki Department of Forest Ecology Publications $31: 1-123$

Leps J, Smilauer P (2003) Multivariate analysis of ecological data using CANOCO. Cambridge University Press, Cambridge

Limpens J, Berendse F (2003) How litter quality affects mass loss and N loss from decomposing Sphagnum. Oikos 103:537-547

Liski J, Palosuo T, Peltoniemi M, Sievänen R (2005) Carbon and decomposition model Yasso for forest soils. Ecological Modelling 189:168-182

Mäkiranta P, Minkkinen K, Hytönen J, Laine J (2008) Factors causing temporal and spatial variation in heterotrophic and rhizospheric components of soil respiration in afforested organic soil croplands in Finland. Soil Biology and Biochemistry 40:1592-1600

Malmer N, Albinsson C, Svensson BM, Wallén B (2003) Interferences between Sphagnum and vascular plants: effects on plant community structure and peat formation Oikos 100:469-482

McClaugherty CA, Pastor J, Aber JD, Melillo JM (1985) Forest Litter Decomposition in Relation to Soil Nitrogen Dynamics and Litter Quality. Ecology 66:266-275

Meentemeyer V (1978) Macroclimate and lignin control of decomposition rates. Ecology 59:465-472

Minkkinen K, Laine J, Shurpali NJ, Mäkiranta P, Alm J, Penttilä T (2007) Heterotrophic soil respiration in forestry-drained peatlands. Boreal Environment Research 12:115-126 
Moore TR, Trofymow JA, Taylor B, et al (1999) Litter decomposition rates in Canadian forests. Global Change Biology 5:75-82

Moorhead DL, Reynolds JF (1991) A general model of litter decomposition in the northern Chihuahuan Desert. Ecological Modelling 59:197-219

Murphy KL, Klopatek JM, Klopatek CC (1998) The effects of litter quality and climate on decomposition along an elevational gradient. Ecological Applications 8:1061-1071.

Murphy M, Laiho R, Moore TR (2009) Effects of water table drawdown on root production and aboveground biomass in a boreal bog. Ecosystems 12:12681282.

Nilsson M-C, Wardle DA, DeLuca TH (2008) Belowground and aboveground consequences of interactions between live plant species mixtures and dead organic substrate mixtures. Oikos 117:439-449

Päivänen J, Vasander H (1994) Carbon balance in mire ecosystems. World Resource Review 6:102-111

Parton WJ, Schimel DS, Cole CV, Ojima DS (1987) Analysis of factors controlling soil organic matter levels in Great Plains Grasslands. Soil Science Society of America Journal 51:1173-1179

Preston CM, Trofymow JA, CIDET Working Group (2000) Variability in litter quality and its relationship to litter decay in Canadian forests. Canadian Journal of Botany 78:1269-1287

Prevost M, Plamondon AP, Belleau P (1999) Effects of drainage of a forested peatland on water quality and quantity. Journal of Hydrology 214:130-143

Quarmby C, Allen SE (1989) Organic constituents. In: Allen SE (ed) Chemical Analysis of Ecological Materials. Wiley, New York, pp 160-201

Quested HM, Cornelissen JHC, Press MC, et al (2003) Decomposition of sub-arctic plants with differing nitrogen economies: A functional role for hemiparasites. Ecology 84:3209-3221

Rasmussen S, Wolff C, Rudolph H (1995) Compartmentalization of phenolic constituents in Sphagnum. Phytochemistry 38:35-39

Rastetter EB, Ryan MG, Shaver GR, Melillo JM, Nadelhoffer KJ, Hobbie JE, Aber JD (1991) A general model describing the responses of the $\mathrm{C}$ and $\mathrm{N}$ cycles in terrestrial ecosystems to changes in $\mathrm{CO}_{2}$, climate, and $\mathrm{N}$ deposition. Tree Physiology 9:101-126

Roulet N, Moore T, Bubier J, Lafleur P (1992) Northern fens: methane flux and climatic change. Tellus 44B:100-105

Roulet, N.T, Lafleur, P.M, Richard, P.J.H, Moore, T.R, Humphreys, E.R, Bubier, J (2007) Contemporary carbon balance and late Holocene carbon accumulation in a northern peatland. Global Change Biology 13:397-411

Ryan MG, Melillo JM, Ricca A (1990) A comparison of methods for determining proximate carbon fractions of forest litter. Canadian Journal of Forest Research 20:166-171

Saarinen T (1996) Biomass and production of two vascular plants in a boreal mesotrophic fen. Canadian Journal of Botany 74:934-938 
Saiya-Cork KR, Sinsabaugh RL, Zak DR (2002) The effects of long term nitrogen deposition on extracellular enzyme activity in an Acer saccharum forest soil. Soil Biology and Biochemistry 34:1309-1315

Saleska SR, Shaw MR, Fischer ML, Dunne JA, Still CJ, Holman ML, Harte J (2002) Plant community composition mediates both large transient decline and predicted long-term recovery of soil carbon under climate warming. Global Biogeochemical Cycles 16:1055-1072

Sallantaus T (1992) Leaching in the material balance of peatlands - preliminary results. Suo 43:253-258

Sariyildiz T, Anderson JM (2003) Interactions between litter quality, decomposition and soil fertility: a laboratory study. Soil Biology and Biochemistry 35:391-399

Scowcroft PS (1997) Mass and nutrient dynamics of decaying litter from Passiflora mollissima and selected native species in a Hawaiian montane rain forest. Journal of Tropical Ecology 13:407-426

Silins U, Rothwell RL (1999) Spatial patterns of aerobic limit depth and oxygen diffusion rate at two peatlands drained for forestry in Alberta. Canadian Journal of Forest Research 29:53-61

Sjöberg G, Nilsson SI, Persson T, Karlsson P (2004) Degradation of hemicellulose, cellulose and lignin in decomposing spruce needle litter in relation to N. Soil Biology and Biochemistry 36:1761-1768

Stohlgren TJ (1988) Litter dynamics in two Sierran mixed conifer forests, II: Nutrient release in decomposing leaf litter. Canadian Journal of Forest Research 18:11361144

Suding KN, Lavorel S, Chapin FS, et al (2008) Scaling environmental change through the community-level: a trait-based response-and-effect framework for plants. Global Change Biology 14:1125-1140

Sundberg A, Pranovich AV, Holmbom B (2003) Chemical characterization of various types of mechanical pulp fines. Journal of Pulp and Paper Science 29:173-178

Sundberg A, Sundberg K, Lillandt C, Holmbom B (1996) Determination of hemicelluloses and pectins in wood and pulp fibres by acid methanolysis and gas chromatography. Nordic Pulp and Paper Research Journal 11:216-219

Szumigalski AR, Bayley SE (1996) Decomposition along a bog to rich fen gradient in central Alberta, Canada. Canadian Journal of Botany 74:573-581

Talbot J, Richard PJH, Roulet NT, Booth RK (2010) Assessing long-term hydrological and ecological responses to drainage in a raised bog using paleoecology and a hydrosequence. Journal of Vegetation Science 21:143-156

Taylor BR, Parkinson D, Parsons WJF (1989) Nitrogen and lignin content as predictors of litter decay rates: a microcosm test. Ecology 70:97-104

Taylor BR, Prescott CE, Parsons WJF, Parkinson D (1991) Substrate control of litter decomposition in four Rocky Mountain coniferous forests. Canadian Journal of Botany 69:2242-2250

ter Braak, CJ., Smilauer, P (2002). CANOCO for Windows. Version 4.5. Biometris Plant Research International, Wageningen, The Netherlands 
Thormann MN, Bayley SE, Currah RS (2001) Comparison of decomposition of belowground and aboveground plant litters in peatlands of boreal Alberta, Canada. Canadian Journal of Botany 79:9-22

Tian G, Kang BT, Brussaard L (1992) Biological effects of plant residues with contrasting chemical compositions under humid tropical conditionsDecomposition and nutrient release. Soil Biology and Biochemistry 24:10511060

Turetsky MR, Crow SE, Evans RJ, Vitt DH, Wieder KR (2008) Trade-offs in resource allocation among moss species control decomposition in boreal peatlands. Journal of Ecology 96:1297-1305

Verhoeven JTA, Liefveld WM (1997) The ecological significance of organochemical compounds in Sphagnum. Acta Botanica Neerlandica 46:117-130

Wallén B (1992) Methods for studying below-ground production in mire ecosystems. Suo 43:155-162

Wallén B (1986) Above and below ground dry mass of the three main vascular plants on hummocks on a subarctic peat bog. Oikos 46:51-56

Wania R, Ross I, Prentice IC (2009) Integrating peatlands and permafrost into a dynamic global vegetation model: II. Evaluation and sensitivity of vegetation and carbon cycle processes. Global Biogeochemical Cycles 23, GB3015, doi: $10.1029 / 2008$ GB003413

Weatherly HE, Zitzer SF, Coleman JS, Arnone JAI (2003) In situ litter decomposition and litter quality in a Mohave Desert ecosystem: effects of elevated atmospheric CO2 and interannual climate variability. Global Change Biology 9:1223-1233

Weltzin JF, Bridgham SD, Pastor J, Chen JQ, Harth C (2003) Potential effects of warming and drying on peatland plant community composition. Global Change Biology 9:141-151

Weltzin JF, Pastor J, Harth C, Bridgham SD, Updegraff K, Chapin CT (2000) Response of bog and fen plant communities to warming and water-table manipulations. Ecology 81:3464-3478

Wieder RK, Starr ST (1998) Quantitative determination of organic fractions in highly organic, Sphagnum peat soils. Communications in Soil Science and Plant Analysis 29:847-857

Williams CJ, Yavitt JB, Wieder RK, Cleavitt NL (1998) Cupric oxide oxidation products of northern peat and peat-forming plants. Canadian Journal of Botany 76:51-62

Wilson MA, Sawyer J, Hatcher PG, Lerch HE (1989) 1-3-5 Hydroxybenzene structures in mosses. Phytochemistry 28:1395-1400

Zhang Y, Li C, Trettin C, Li H, Sun G (2002) An integrated model of soil, hydrology, and vegetation for carbon dynamics in wetland ecosystems. Global Biogeochemical Cycles 16, 1061, doi:10.1029/2001GB001838 
Table 1. Average soil nutrient and ash concentrations ( $\mathrm{mg} \cdot \mathrm{g}^{-1}$ of dry mass) and $\mathrm{pH}$ at the study plots in $0-10 \mathrm{~cm}$ depth. Standard error of mean in parenthesis, $\mathrm{n}=3$.

\begin{tabular}{|c|c|c|c|c|c|c|c|c|c|c|c|c|}
\hline site nutrient regime & WL regime & microform & $\mathrm{C}$ & $\mathrm{N}$ & $\mathrm{P}$ & $\mathrm{K}$ & $\mathrm{Ca}$ & $\mathrm{Mg}$ & $\mathrm{Mn}$ & $\mathrm{Fe}$ & ash & $\mathrm{pH}$ \\
\hline $\mathrm{ME}$ & PR & & $447(9.5)$ & $21.1(2.1)$ & $0.85(0.08)$ & $1.02(0.02)$ & $5.91(0.80)$ & $7.74(0.54)$ & $0.46(0.05)$ & $13.27(4.52)$ & $142(11.6)$ & $5.9(0.2)$ \\
\hline $\mathrm{ME}$ & STD & & $448(1.0)$ & $20.8(1.5)$ & $0.93(0.04)$ & $1.02(0.09)$ & $8.32(1.23)$ & $11.63(1.56)$ & $0.74(0.20)$ & $12.17(0.43)$ & $107(8.0)$ & $5.4(0.2)$ \\
\hline $\mathrm{ME}$ & LTD & & $488(9.0)$ & $15.2(1.1)$ & $0.70(0.07)$ & $0.85(0.02)$ & $3.18(0.35)$ & $5.16(0.26)$ & $0.38(0.13)$ & $2.65(0.98)$ & 27 (1.6) & $3.8(0.1)$ \\
\hline OL & PR & & $462(1.3)$ & $12.3(0.4)$ & $0.34(0.02)$ & $0.96(0.14)$ & $5.41(0.12)$ & $9.34(0.40)$ & $2.54(0.19)$ & $13.74(3.28)$ & $54(5.9)$ & $4.6(0.1)$ \\
\hline $\mathrm{OL}$ & STD & & $474(6.1)$ & $13.6(1.2)$ & $0.40(0.03)$ & $1.16(0.21)$ & $6.83(1.20)$ & $12.39(2.73)$ & $3.50(1.16)$ & $12.12(1.52)$ & $52(1.3)$ & $4.9(0.3)$ \\
\hline $\mathrm{OL}$ & LTD & & $488(5.5)$ & $22.1(2.0)$ & $1.33(0.12)$ & $0.73(0.20)$ & $3.72(0.47)$ & $2.79(0.35)$ & $0.45(0.13)$ & $7.58(1.11)$ & $71(2.1)$ & $3.8(0.1)$ \\
\hline $\mathrm{OM}$ & PR & Ho & $487(1.5)$ & $8.3(0.3)$ & $0.19(0.02)$ & $0.66(0.03)$ & $0.80(0.02)$ & $3.66(0.28)$ & $0.37(0.05)$ & $0.36(0.04)$ & $10(1.1)$ & $4.0(0.1)$ \\
\hline $\mathrm{OM}$ & PR & $\mathrm{Hu}$ & $493(3.7)$ & $9.2(0.7)$ & $0.24(0.03)$ & $2.02(0.03)$ & $1.50(0.03)$ & $4.58(0.10)$ & $2.72(0.43)$ & $0.28(0.01)$ & $14(0.6)$ & $4.0(0.1)$ \\
\hline $\mathrm{OM}$ & PR & $\mathrm{La}$ & $490(3.7)$ & $8.7(0.3)$ & $0.17(0.03)$ & $1.92(0.04)$ & $1.18(0.06)$ & $4.91(0.14)$ & $1.10(0.19)$ & $0.39(0.05)$ & $13(0.8)$ & $4.4(0.1)$ \\
\hline $\mathrm{OM}$ & STD & Ho & $464(4.0)$ & $10.9(1.2)$ & $0.30(0.03)$ & $0.60(0.08)$ & $1.02(0.01)$ & $4.60(0.24)$ & $0.66(0.04)$ & $0.47(0.04)$ & $17(2.4)$ & $4.0(0.1)$ \\
\hline $\mathrm{OM}$ & STD & $\mathrm{Hu}$ & $483(2.3)$ & $9.2(0.1)$ & $0.28(0.04)$ & $1.31(0.02)$ & $1.59(0.15)$ & $5.22(0.04)$ & $3.14(0.60)$ & $0.30(0.02)$ & $13(0.1)$ & $4.0(0.1)$ \\
\hline $\mathrm{OM}$ & STD & $\mathrm{La}$ & $477(3.0)$ & $10.9(1.3)$ & $0.29(0.04)$ & $1.15(0.03)$ & $1.18(0.05)$ & $5.23(0.27)$ & $1.46(0.36)$ & $0.44(0.08)$ & $12(0.7)$ & $3.8(0.1)$ \\
\hline OM & LTD & & $504(5.3)$ & $14.8(0.6)$ & $0.81(0.06)$ & $0.79(0.07)$ & $2.92(0.16)$ & $4.70(0.78)$ & $1.55(0.29)$ & $0.90(0.02)$ & $31(1.0)$ & $3.7(0.2)$ \\
\hline
\end{tabular}

Site nutrient and water level (WL) regimes: LTD long-term WL drawdown; ME, mesotrophic fen (minerotrophic); OL, oligotrophic fen (minerotrophic); OM, bog (ombrotrophic); PR pristine; STD short-term WL drawdown. Microforms: Ho, hollow; Hu, hummock; La, lawn level. WL, water level. 
Table 2. Percentage of the total variation in litter quality and inputs explained by litter type, site and drainage.

\begin{tabular}{lcccc}
\hline Main effect & $\begin{array}{l}\text { Litter quality parameters } \\
\text { (common litters) }\end{array}$ & $\begin{array}{l}\text { Litter } \\
\text { inputs }\end{array}$ & $\begin{array}{l}\text { Inputs of litter } \\
\text { quality parameters }\end{array}$ & $\begin{array}{l}\text { Overall litter quality at } \\
\text { the community level }\end{array}$ \\
\hline litter type & $88.0^{* * *}$ & & & \\
site & $0.7^{*}$ & $9.61^{* *}$ & $0.5^{\mathrm{NS}}$ & $2.1^{* *}$ \\
drainage & $1.0^{* *}$ & $16.65^{* *}$ & $9.9^{* *}$ & $3.9^{* *}$ \\
\hline
\end{tabular}

${ }^{* *} \mathrm{p} \leq 0.001 ;{ }^{*} \mathrm{p} \leq 0.05 ;{ }^{\mathrm{NS}}$ nonsignificant. 
Table 3. Recommended separation of plant functional types (PFT) and litter types within PFTs for modelling peatland C dynamics, based on litter quality.

PFTs and litter types to be distinguished

1. Needle-leaved arboreal plants: foliar litter

2. Needle-leaved arboreal plants: woody litter

3. Broad-leaved arboreal plants: foliar litter

4. Broad-leaved arboreal plants: woody litter

5. Herbs

6. Minerotrophic graminoids

7. Ombrotrophic graminoids

8. Sphagnum mosses: hummock species

9. Sphagnum mosses: lawn and hollow species

10. Feather mosses
Species representing the PFTs in our material

\section{Pinus sylvestris}

Pinus sylvestris

Betula nana, B. pubescens, Ledum palustre, Vaccinium uliginosum

Betula nana, B. pubescens

Rubus chamaemorus

Carex lasiocarpa, C. rostrata

Eriophorum vaginatum

S. russowii, S. magellanicum, S. fuscum; S. papillosum grouped with these species S. fallax, S. balticum, S. cuspidatum; $S$. angustifolium grouped with these species Pleurozium schreberi 

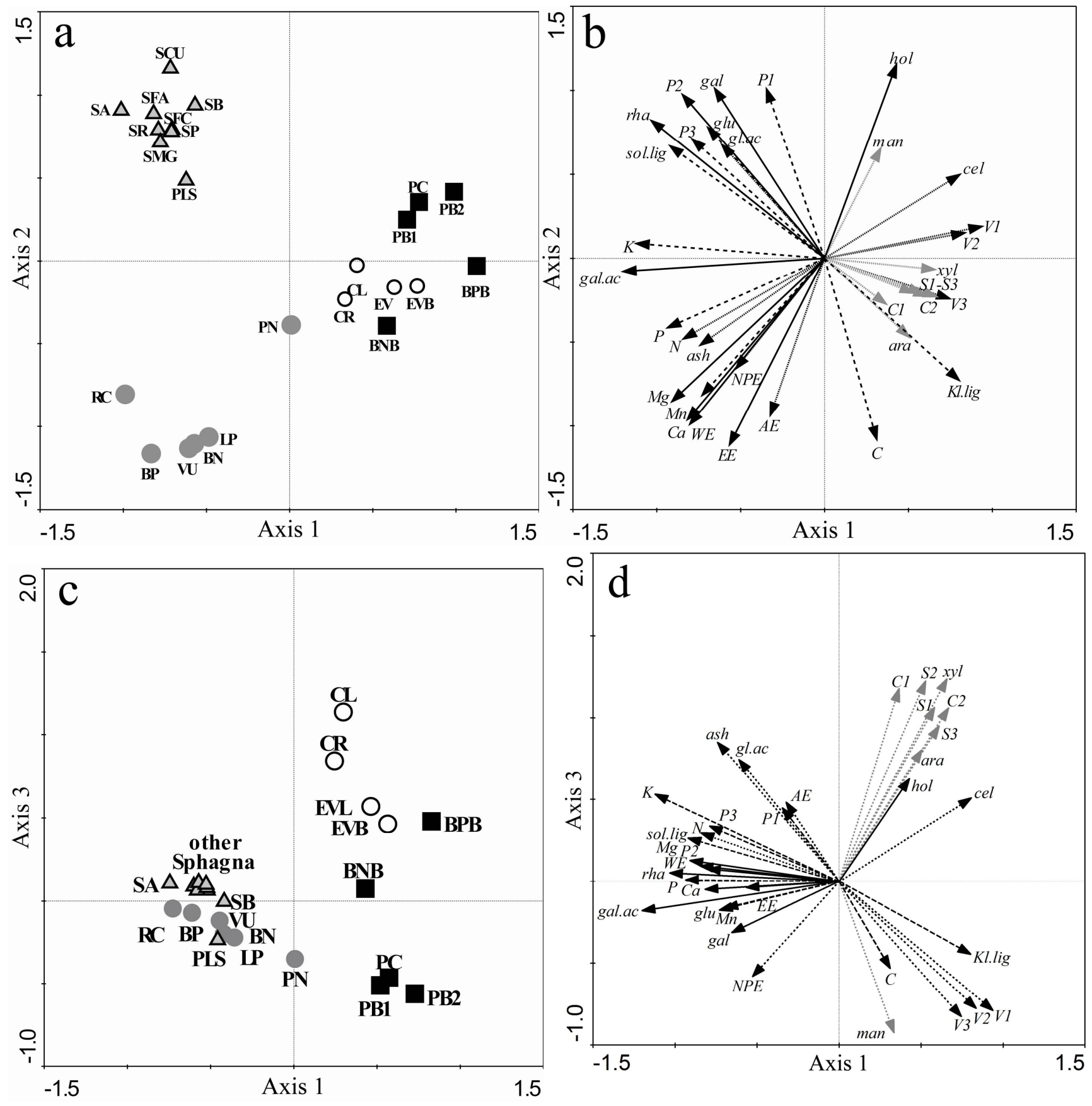

Fig. 1. Ordination diagram from principal component analysis (PCA) showing relations between litter quality parameters of different litter types. The (a) and (b) diagram shows the first and second PCA axes, the (c) and (d) diagram the first and third PCA axes. The first, second, and third axes account for $29.3 \%, 22.3 \%$ and $18.2 \%$ of the total variation, respectively. Gray circles = non-graminoid foliar litters; white circles $=$ graminoid litters; squares $=$ woody litters; triangles $=$ mosses. Litter quality parameters with a fit range of 70-100\% (i.e. of whose variation the first and second axes explained at least 70\%) are shown as full arrows, parameters with a fit range of 50-69\% as dashed arrows, parameters with a fit range of 30-49\% as dotted black arrows and parameters with a fit range of 0-29\% as dotted grey arrows. Litter types: BN, Betula nana leaves; BNB, B. nana branches; BP, B. pubescens leaves; BPB, B. pubescens branches; CL, Carex. lasiocarpa leaves; CR, C. rostrata leaves; EV, Eriophorum vaginatum leaves; EVB, E. vaginatum basal sheaths; LP, Ledum palustre leaves; PB1, Pinus sylvestris branches (diameter $\leq 1 \mathrm{~cm})$; $\mathrm{PB} 2, P$. sylvestris branches (diameter 1-2 cm); PC, P. sylvestris cones; PN, P. sylvestris needles; RC, Rubus chamaemorus; SA, Sphagnum angustifolium; SB, S. balticum; SCU, S. cuspidatum; SFA, S. fallax; SFC, S. fuscum; SMG, S. magellanicum; SP, S. papillosum; SR, S. rusowii; PLS, Pleurozium schreberi; VU, Vaccinium uliginosum leaves. Litter quality parameters: ara, arabinose; AE, acetone extractives; C1, p-coumaric acid; C2, ferulic acid; cel, cellulose; EE, ethanol extractives; gal, galactose; gal.ac, galacturonic acid; gl.ac, glucuronic acid; glu, glucose; hol, holocellulose; Kl.lig, Klason lignin; man, mannose; NPE, non-polar (dichloromethane) extractives; P1, 4-hydroxybenzaldehyde; P2, 4-hydroxyacetophenone; P3, 4hydroxybenzoic acid; rha, rhamnose; S1, syringe aldehyde; S2, acetosyringone; S3, syringic acid; sol.lig, soluble lignin; V1, vanillin; V2, vanillic acid; V3, acetovanillone; WE, water extractives; xyl, xylose. 

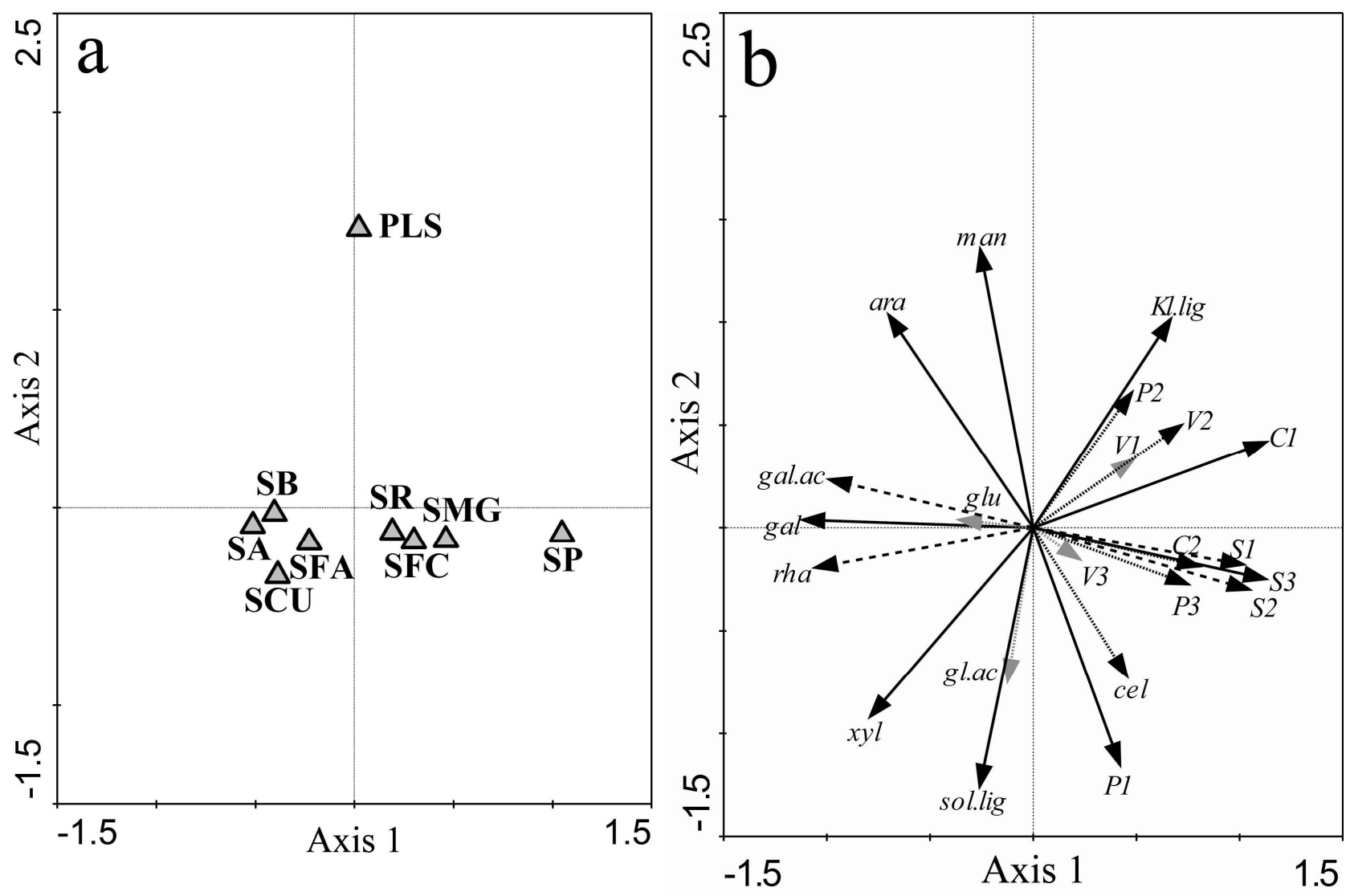

Fig. 2. Ordination diagram from principal component analysis (PCA) showing relations between selected litter quality parameters of different moss species. The first and second axes account for $32.0 \%$ and $21.1 \%$ of the total variation, respectively. Litter quality parameters with a fit range of $70-100 \%$ (i.e. of whose variation the first and second axes explained at least 70\%) are shown as full arrows, parameters with a fit range of 50-69\% as dashed arrows, parameters with a fit range of 30-49\% as dotted black arrows and parameters with a fit range of $0-29 \%$ as dotted grey arrows. See Fig. 1 for the abbreviations. 


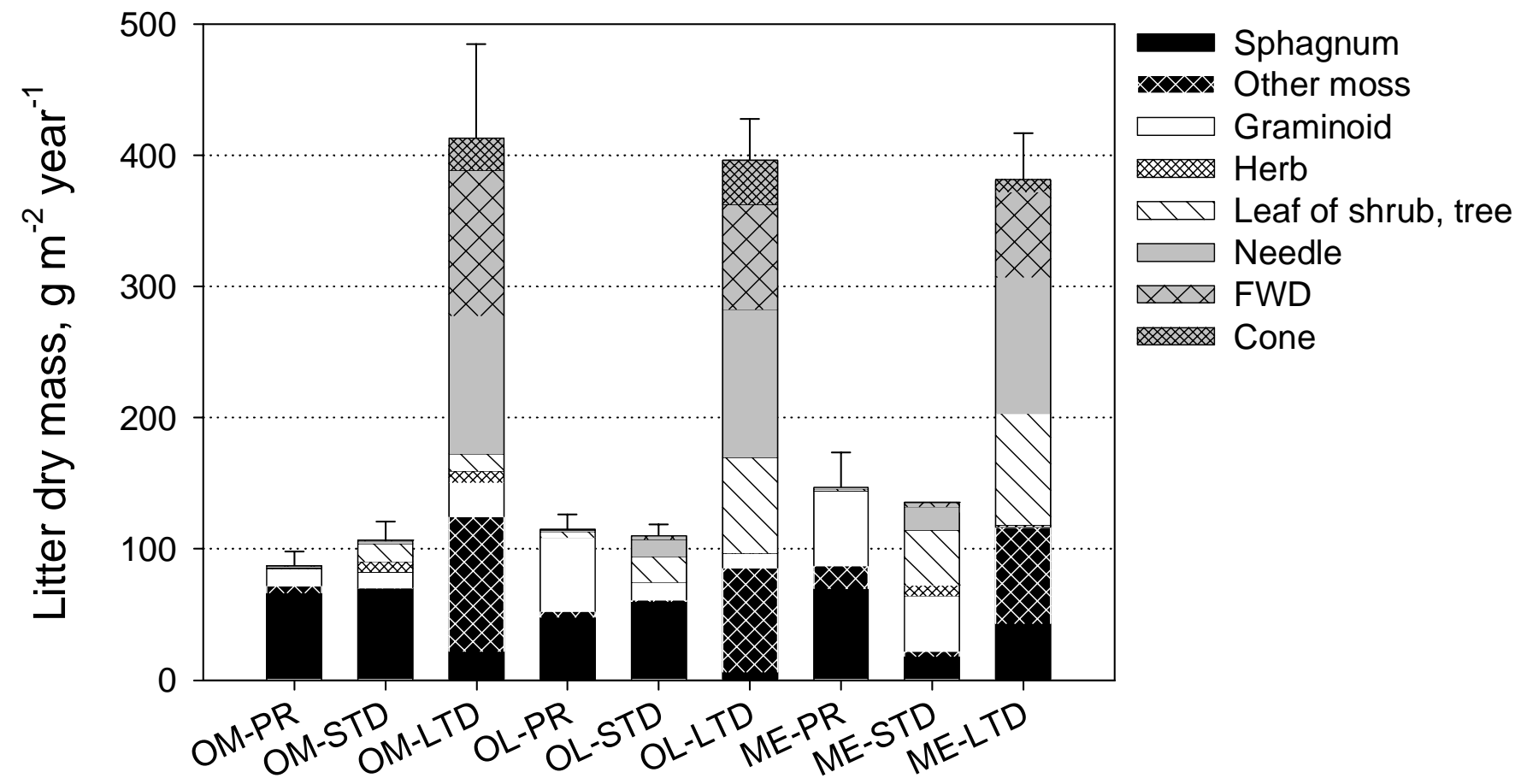

Fig. 3. Litter inputs per different nutrient and water level regimes. The error bars show standard errors for the total litter production per given nutrient and water level regime. FWD, fine woody debris (twigs, branches, bark). See Table 1 for the other abbreviations.

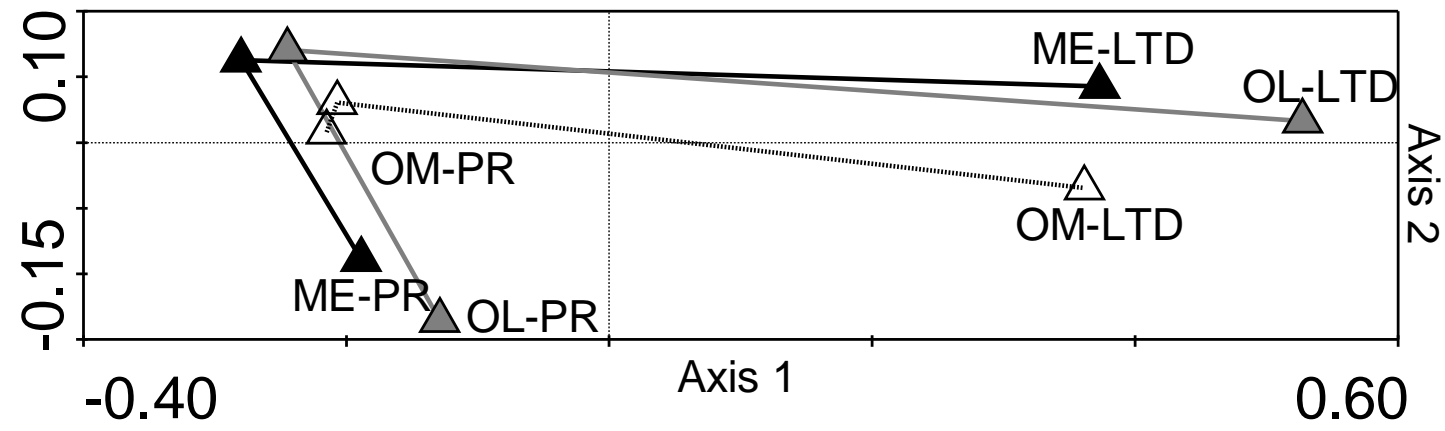

Fig. 4. Ordination diagram from redundancy analysis (RDA) of the variation in the inputs of litter quality parameters (depending on the quality of each litter type and its input) between different water level regimes. The combined effects of site and drainage are projected into the ordination diagram as supplementary variables. The first and second axes account for $9.0 \%$ and $0.3 \%$ of the total variation, respectively. Labels for the STD plots are not shown for the clarity of the diagram. See Table1 for the abbreviations. 

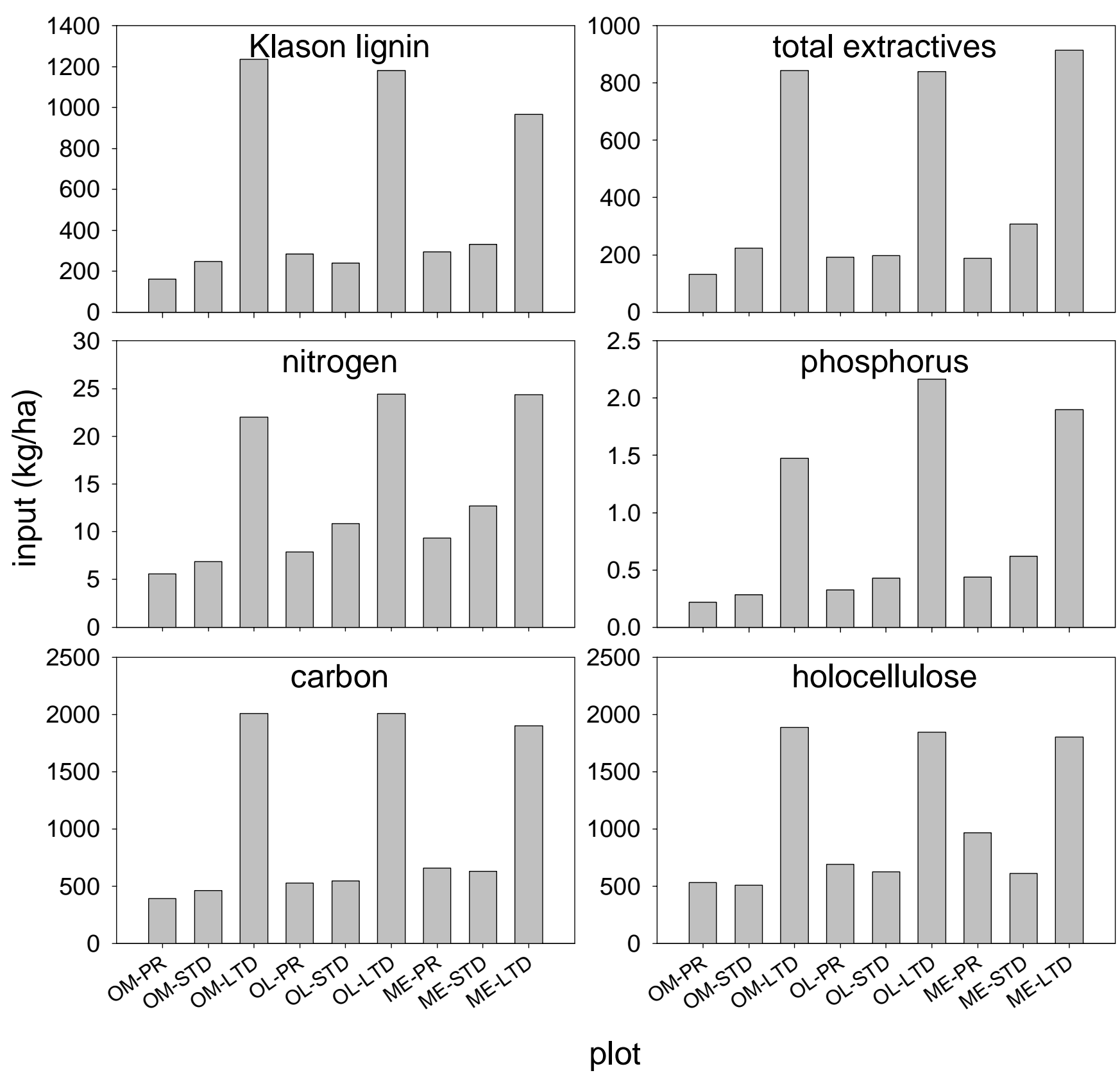

Fig. 5. Inputs of selected individual litter quality parameters per different nutrient and water level regimes. Total extractives are sum of nonpolar-, acetone-, ethanol- and water-extractives. See Table 1 and Fig. 1 for the abbreviations. 

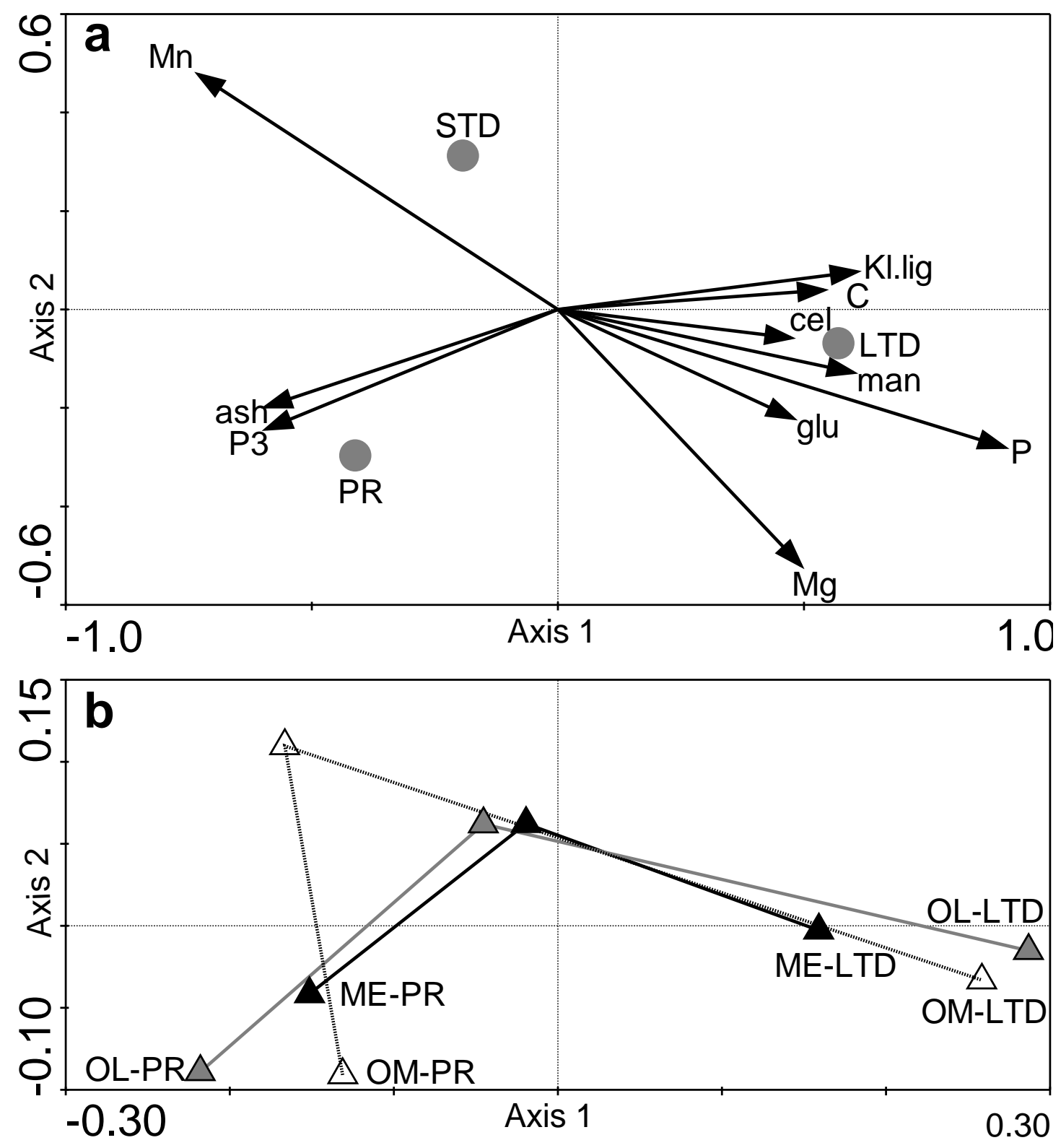

Fig. 6. Ordination diagram from redundancy analysis (RDA) showing (a) variation in the overall litter quality at the community level between different water level regimes (b) with the combined effects of site and drainage projected into the ordination diagram as supplementary variables. Included in the (a) plot are such litter quality parameters of whose variation the first and second axes explained at least 3\% (i.e. 32 parameters were reduced to 10). Labels for the STD plots are not shown for the clarity of the (b) diagram. The first and second axes account for $3.2 \%$ and $0.4 \%$ of the total variation, respectively. See Table 1 and Fig. 1 for the abbreviations. 
Appendix 1. Litter quality parameters, mean values per litter type ( $\mathrm{mg} \cdot \mathrm{g}^{-1}$ of dry mass) with standard error of mean in parentheses. The standard error indicates variation in litter quality between plots of different nutrient and/or water level regimes.

\begin{tabular}{|c|c|c|c|c|c|c|c|c|c|c|c|c|c|c|c|c|c|c|c|}
\hline \multirow{2}{*}{$\begin{array}{l}\text { litter } \\
\text { type }\end{array}$} & \multirow[b]{2}{*}{$\mathrm{n}$} & \multicolumn{3}{|c|}{ OM } & \multicolumn{3}{|c|}{$\mathrm{OL}$} & \multicolumn{3}{|c|}{ ME } & \multirow[b]{2}{*}{ ash } & \multirow[b]{2}{*}{$\mathrm{N}$} & \multirow[b]{2}{*}{$P$} & \multirow[b]{2}{*}{$\mathrm{Ca}$} & \multirow[b]{2}{*}{ K } & \multirow[b]{2}{*}{$\mathrm{Mg}$} & \multirow[b]{2}{*}{ Mn } & \multirow[b]{2}{*}{$\mathrm{C}$} & \multirow[b]{2}{*}{$\mathrm{C}: \mathrm{N}$} \\
\hline & & $\mathrm{PR}$ & STD & LTD & $\mathrm{PR}$ & STD & LTD & $\mathrm{PR}$ & STD & LTD & & & & & & & & & \\
\hline PN & 9 & $\mathrm{x}$ & $\mathrm{x}$ & $\mathrm{x}$ & $\mathrm{x}$ & $\mathrm{x}$ & $\mathrm{x}$ & $\mathrm{x}$ & $\mathrm{x}$ & $\mathrm{x}$ & $19.07(0.88)$ & $4.37(0.37)$ & $0.175(0.019)$ & $5.53(0.35)$ & $0.99(0.10)$ & $0.607(0.042)$ & $0.922(0.103)$ & $557.4(1.0)$ & $133.3(9.0)$ \\
\hline $\mathrm{PC}$ & 9 & $\mathrm{x}$ & $\mathrm{x}$ & $\mathrm{x}$ & $\mathrm{x}$ & $\mathrm{x}$ & $\mathrm{x}$ & $\mathrm{x}$ & $\mathrm{x}$ & $\mathrm{x}$ & $3.55(0.19)$ & $3.13(0.37)$ & $0.123(0.008)$ & $0.43(0.07)$ & $0.39(0.08)$ & $0.212(0.056)$ & $0.024(0.003)$ & $490.1(4.6)$ & $155.3(17.3)$ \\
\hline PB1 & 9 & $\mathrm{x}$ & $\mathrm{x}$ & $\mathrm{x}$ & $\mathrm{x}$ & $\mathrm{x}$ & $\mathrm{x}$ & $\mathrm{x}$ & $\mathrm{x}$ & $\mathrm{x}$ & $9.83(0.60)$ & $6.29(0.72)$ & $0.194(0.035)$ & $1.82(0.25)$ & $0.35(0.05)$ & $0.126(0.025)$ & $0.034(0.009)$ & $501.9(3.2)$ & $90.3(8.3)$ \\
\hline PB2 & 9 & $\mathrm{x}$ & $\mathrm{x}$ & $\mathrm{x}$ & $\mathrm{x}$ & $\mathrm{x}$ & $\mathrm{x}$ & $\mathrm{x}$ & $\mathrm{x}$ & $\mathrm{x}$ & $3.76(0.72)$ & $3.02(0.24)$ & $0.076(0.020)$ & $0.93(0.19)$ & $0.15(0.03)$ & $0.069(0.017)$ & $0.019(0.004)$ & $493.0(2.5)$ & $174.5(11.4)$ \\
\hline $\mathrm{BN}$ & 9 & $\mathrm{x}$ & $\mathrm{x}$ & $\mathrm{x}$ & $\mathrm{x}$ & $\mathrm{x}$ & $\mathrm{x}$ & $\mathrm{x}$ & $\mathrm{x}$ & $\mathrm{x}$ & $26.54(0.76)$ & $9.78(1.46)$ & $0.677(0.124)$ & $5.94(0.09)$ & $2.88(0.45)$ & $2.031(0.076)$ & $1.609(0.196)$ & $535.5(2.9)$ & $62.8(7.1)$ \\
\hline $\mathrm{BNB}$ & 4 & $\mathrm{x}$ & & $\mathrm{x}$ & $\mathrm{x}$ & $\mathrm{x}$ & & & & & $11.63(0.51)$ & $7.85(0.16)$ & $0.418(0.039)$ & $2.78(0.13)$ & $0.89(0.10)$ & $0.437(0.019)$ & $0.464(0.065)$ & $532.2(3.7)$ & $67.9(1.9)$ \\
\hline $\mathrm{BP}$ & 3 & & & $\mathrm{x}$ & & & $\mathrm{x}$ & & & $\mathrm{x}$ & 37.47 (3.93) & $8.11(0.84)$ & $1.011(0.089)$ & $9.09(1.27)$ & $3.61(0.38)$ & $3.360(0.225)$ & $0.881(0.088)$ & $509.2(4.1)$ & $64.4(7.6)$ \\
\hline ВРB & 3 & & & $\mathrm{x}$ & & & $\mathrm{x}$ & & & $\mathrm{x}$ & $10.26(1.04)$ & $3.15(0.26)$ & $0.112(0.014)$ & $3.03(0.46)$ & $0.29(0.03)$ & $0.396(0.018)$ & $0.143(0.044)$ & $490.4(5.2)$ & $157.6(12.6)$ \\
\hline $\mathrm{CR}$ & 4 & & & & $\mathrm{x}$ & $\mathrm{x}$ & & $\mathrm{x}$ & $\mathrm{x}$ & & $45.28(3.52)$ & $7.70(0.42)$ & $0.181(0.012)$ & $3.38(0.19)$ & $3.17(0.07)$ & $1.010(0.094)$ & $0.200(0.084)$ & $477.2(1.0)$ & $62.5(3.2)$ \\
\hline $\mathrm{CL}$ & 4 & & & & $\mathrm{x}$ & $x$ & & $\mathrm{x}$ & $\mathrm{x}$ & & $54.60(4.52)$ & $7.80(0.84)$ & $0.156(0.028)$ & $3.52(0.32)$ & $3.54(0.70)$ & $0.733(0.066)$ & $0.302(0.118)$ & $463.2(2.5)$ & $61.4(6.5)$ \\
\hline EV & 9 & $\mathrm{x}$ & $\mathrm{x}$ & $\mathrm{x}$ & $\mathrm{x}$ & $\mathrm{x}$ & $\mathrm{x}$ & $\mathrm{x}$ & $\mathrm{x}$ & $\mathrm{x}$ & $19.18(1.28)$ & $6.14(0.20)$ & $0.184(0.026)$ & $2.15(0.08)$ & $1.29(0.14)$ & $0.852(0.108)$ & $0.287(0.061)$ & $494.7(1.4)$ & $81.3(2.7)$ \\
\hline EVB & 9 & $\mathrm{x}$ & $\mathrm{x}$ & $\mathrm{x}$ & $\mathrm{x}$ & $\mathrm{x}$ & $\mathrm{x}$ & $\mathrm{x}$ & $\mathrm{x}$ & $\mathrm{x}$ & $16.14(2.61)$ & $5.05(0.54)$ & $0.276(0.056)$ & $1.10(0.19)$ & $0.89(0.09)$ & $0.333(0.038)$ & $0.125(0.025)$ & $484.4(1.7)$ & $103.6(9.3)$ \\
\hline $\mathrm{RC}$ & 4 & $\mathrm{x}$ & $\mathrm{x}$ & $\mathrm{x}$ & & & & & & $\mathrm{x}$ & $31.33(0.93)$ & $15.56(1.20)$ & $0.728(0.116)$ & $6.52(0.78)$ & $3.61(0.62)$ & $3.055(0.503)$ & $0.833(0.213)$ & $485.7(1.8)$ & $31.8(2.4)$ \\
\hline VU & 5 & $\mathrm{x}$ & $\mathrm{x}$ & $\mathrm{x}$ & & & $\mathrm{x}$ & & & $\mathrm{x}$ & $36.18(1.68)$ & $8.00(0.88)$ & $0.427(0.103)$ & $9.25(0.31)$ & $3.44(0.46)$ & $2.268(0.303)$ & $0.783(0.077)$ & $511.5(1.8)$ & $67.3(7.7)$ \\
\hline LP & 5 & $\mathrm{x}$ & $\mathrm{x}$ & $\mathrm{x}$ & & & $\mathrm{x}$ & & & $\mathrm{x}$ & $33.62(1.61)$ & $8.73(0.17)$ & $0.469(0.038)$ & $9.17(0.54)$ & $1.37(0.08)$ & $1.910(0.196)$ & $1.788(0.163)$ & $552.1(3.6)$ & $63.4(1.2)$ \\
\hline PLS & 3 & & & $\mathrm{x}$ & & & $\mathrm{x}$ & & & $\mathrm{x}$ & $20.30(1.27)$ & $7.75(0.49)$ & $0.775(0.073)$ & $2.74(0.25)$ & $3.49(0.25)$ & $0.875(0.064)$ & $0.286(0.091)$ & $455.9(8.0)$ & $59.1(2.7)$ \\
\hline SA & 9 & $\mathrm{x}$ & $\mathrm{x}$ & $\mathrm{x}$ & $\mathrm{x}$ & $\mathrm{x}$ & $\mathrm{x}$ & $\mathrm{x}$ & $\mathrm{x}$ & $\mathrm{x}$ & $25.21(1.57)$ & $7.85(0.65)$ & $0.544(0.069)$ & $3.94(0.31)$ & $3.80(0.11)$ & $1.096(0.103)$ & $0.811(0.138)$ & $434.4(6.4)$ & $57.8(4.0)$ \\
\hline SFA & 4 & & & & $\mathrm{x}$ & $\mathrm{x}$ & & $\mathrm{x}$ & $\mathrm{x}$ & & $27.08(2.14)$ & $7.21(1.04)$ & $0.339(0.039)$ & $4.58(0.59)$ & $3.20(0.07)$ & $1.204(0.199)$ & $0.693(0.193)$ & 451.7 (10.5) & $65.7(7.5)$ \\
\hline SP & 4 & & & & $\mathrm{x}$ & $\mathrm{x}$ & & $\mathrm{x}$ & $\mathrm{x}$ & & $25.48(0.77)$ & $7.12(0.65)$ & $0.306(0.023)$ & $3.25(0.12)$ & $3.35(0.55)$ & $0.888(0.074)$ & $0.311(0.021)$ & $464.8(8.1)$ & $66.9(6.0)$ \\
\hline SR & 3 & & & $\mathrm{x}$ & & & $\mathrm{x}$ & & & $\mathrm{x}$ & $20.37(2.38)$ & $6.36(0.14)$ & $0.525(0.082)$ & $2.67(0.51)$ & $3.62(0.43)$ & $0.852(0.142)$ & $0.232(0.083)$ & $447.4(2.2)$ & $70.4(1.4)$ \\
\hline SMG & 3 & & & $\mathrm{x}$ & & & $\mathrm{x}$ & & & $\mathrm{x}$ & $24.40(0.61)$ & $7.98(0.15)$ & $0.691(0.081)$ & $3.11(0.14)$ & $4.07(0.21)$ & $1.200(0.078)$ & $0.284(0.083)$ & $445.6(7.5)$ & $55.8(0.1)$ \\
\hline SB & 2 & $\mathrm{x}$ & $\mathrm{x}$ & & & & & & & & $15.60(2.00)$ & $6.58(0.07)$ & $0.234(0.002)$ & $1.49(0.28)$ & $2.93(0.11)$ & $0.492(0.024)$ & $0.215(0.130)$ & 445.3 (1.9) & $67.7(1.0)$ \\
\hline $\mathrm{SFC}$ & 3 & $\mathrm{x}$ & $\mathrm{x}$ & $\mathrm{x}$ & & & & & & & $18.00(1.00)$ & $6.72(0.31)$ & $0.298(0.055)$ & $2.13(0.31)$ & $2.89(0.33)$ & $0.599(0.038)$ & $0.509(0.151)$ & $449.1(4.2)$ & $67.2(3.2)$ \\
\hline $\mathrm{SCU}$ & 2 & $\mathrm{x}$ & $\mathrm{x}$ & & & & & & & & $20.45(0.45)$ & $6.90(1.50)$ & $0.257(0.032)$ & $0.84(0.03)$ & $3.76(0.12)$ & $0.571(0.032)$ & $0.038(0.013)$ & $475.5(1.5)$ & $72.3(15.5)$ \\
\hline
\end{tabular}

$\mathrm{n}$, number of samples per litter type; $\mathrm{x}$, litter type was sampled at the given nutrient and water level (WL) regime. Nutrient and WL regimes: LTD long-term WL drawdown;

ME, mesotrophic fen (minerotrophic); OL, oligotrophic fen (minerotrophic); OM, bog (ombrotrophic); PR pristine; STD short-term WL drawdown. Litter types: BN, Betula nana leaves; BNB, B. nana branches; BP, B. pubescens leaves; BPB, B. pubescens branches; CL, Carex. lasiocarpa leaves; CR, C. rostrata leaves; EV, Eriophorum vaginatum leaves; EVB, E. vaginatum basal sheaths; LP, Ledum palustre leaves; PB1, Pinus sylvestris branches (diameter $\leq 1 \mathrm{~cm})$; PB2, P. sylvestris branches (diameter 1-2 $\mathrm{cm}$ ); PC, P. sylvestris cones; PN, P. sylvestris needles; RC, Rubus chamaemorus; SA, Sphagnum angustifolium; SB, S. balticum; SCU, S. cuspidatum; SFA, S. fallax; SFC, S. fuscum; SMG, S. magellanicum; SP, S. papillosum; SR, S. russowii; PLS, Pleurozium schreberi; VU, Vaccinium uliginosum leaves. Litter quality parameters: ara, arabinose; $\mathrm{AE}$, acetone extractives; $\mathrm{C} 1$, p-coumaric acid; $\mathrm{C} 2$, ferulic acid; cel, cellulose; C:N, carbon to nitrogen ratio; C:P, carbon to phosphorus ratio; EE, ethanol extractives; gal, galactose; gal.ac, galacturonic acid; gl.ac, glucuronic acid; glu, glucose; hol, holocellulose; Kl.lig, Klason lignin; Kl.lig:N, lignin to nitrogen ratio; man, mannose; NPE, nonpolar (dichloromethane) extractives; P1, 4-hydroxybenzaldehyde; P2, 4-hydroxyacetophenone; P3, 4-hydroxybenzoic acid; rha, rhamnose; S1, syringe aldehyde; S2, acetosyringone; S3, syringic acid; sol.lig, soluble lignin; V1, vanillin; V2, vanillic acid; V3, acetovanillone; WE, water extractives; xyl, xylose. 
Appendix 1 continued

\begin{tabular}{|c|c|c|c|c|c|c|c|c|c|c|c|c|c|c|}
\hline & NPE & $\mathrm{AE}$ & $\mathrm{EE}$ & WE & cel & ara & rha & $\mathrm{xyl}$ & $\operatorname{man}$ & $\mathrm{gal}$ & glu & gl.ac & gal.ac & hol \\
\hline PN & $142.1(3.0)$ & $28.36(1.66)$ & $67.38(3.86)$ & $88.26(2.77)$ & 251.7 (13.9) & $22.46(1.66)$ & $4.84(0.46)$ & $13.76(1.52)$ & $45.36(3.07)$ & $25.69(1.29)$ & $51.99(3.62)$ & $1.21(0.39)$ & $33.65(2.88)$ & $445.8(6.3)$ \\
\hline PC & $24.9(5.0)$ & $7.04(2.48)$ & $12.61(1.90)$ & $27.34(1.62)$ & $339.2(16.7)$ & $11.97(0.48)$ & $1.78(0.23)$ & $18.32(0.86)$ & $111.26(5.62)$ & 26.44 (1.63) & $36.00(1.49)$ & $0(0)$ & $12.62(0.72)$ & $566.6(7.4)$ \\
\hline PB1 & $61.9(7.0)$ & $9.27(1.10)$ & $16.85(2.03)$ & $24.82(1.29)$ & $193.3(20.7)$ & $19.21(1.96)$ & $4.09(0.24)$ & $38.21(4.03)$ & $45.49(2.50)$ & $44.94(2.87)$ & $50.18(4.58)$ & $3.90(1.85)$ & $16.83(1.34)$ & $511.6(15.1)$ \\
\hline $\mathrm{BN}$ & $88.9(2.2)$ & $68.76(4.63)$ & 95.08 (5.07) & $116.93(2.32)$ & $101.6(15.3)$ & $21.89(0.77)$ & $17.70(0.55)$ & $36.26(2.16)$ & $4.08(1.33)$ & $28.15(0.93)$ & $34.75(1.31)$ & $0.96(0.49)$ & $60.38(2.38)$ & $258.3(6.9)$ \\
\hline BNB & $34.8(3.5)$ & $23.89(3.51)$ & $18.43(3.87)$ & $30.73(1.10)$ & $103.6(8.8)$ & $20.32(1.65)$ & $4.77(0.36)$ & $88.04(11.22)$ & $6.87(1.10)$ & $17.95(1.26)$ & $30.10(3.79)$ & $1.08(0.47)$ & $25.44(1.80)$ & $538.4(6.0)$ \\
\hline $\mathrm{BP}$ & $94.6(11.5)$ & $41.48(5.08)$ & $122.66(3.11)$ & $137.88(9.41)$ & $67.7(3.2)$ & $23.96(3.92)$ & $16.53(3.00)$ & $38.76(6.18)$ & $3.32(0.55)$ & $27.98(3.61)$ & $30.96(3.85)$ & $0.93(0.93)$ & $71.37(10.83)$ & $320.9(22.8)$ \\
\hline BPB & $16.4(2.9)$ & $13.97(1.76)$ & $9.47(0.77)$ & $15.63(1.64)$ & $270.8(33.8)$ & $4.62(0.21)$ & $3.85(0.17)$ & $149.47(4.43)$ & $7.43(0.85)$ & $13.44(1.10)$ & $22.62(2.00)$ & $2.25(0.13)$ & $19.26(1.14)$ & $754.6(3.0)$ \\
\hline CL & $31.4(6.0)$ & $26.88(1.33)$ & $25.54(2.99)$ & $58.38(8.70)$ & $333.1(9.9)$ & $46.22(5.78)$ & $2.78(0.18)$ & $163.69(4.89)$ & $3.08(0.18)$ & $20.01(1.89)$ & $35.38(2.81)$ & $20.10(0.47)$ & $14.90(0.83)$ & $622.8(19.4)$ \\
\hline EV & $24.5(0.8)$ & $35.63(1.80)$ & $44.97(1.81)$ & $49.25(1.77)$ & $368.6(40.8)$ & $49.19(2.96)$ & $1.78(0.46)$ & $154.16(6.54)$ & $2.91(0.40)$ & $17.45(0.78)$ & $41.99(2.92)$ & $6.07(2.15)$ & $13.80(1.01)$ & $643.2(9.1)$ \\
\hline EVB & $9.4(1.9)$ & $64.98(2.91)$ & $34.20(2.27)$ & $63.90(5.75)$ & $319.8(24.0)$ & $79.08(6.42)$ & $2.78(0.29)$ & 147.87 (12.99) & $5.18(0.47)$ & $34.47(2.64)$ & $29.59(2.85)$ & $5.77(1.50)$ & $11.25(1.05)$ & $634.9(10.2)$ \\
\hline $\mathrm{RC}$ & $63.5(3.4)$ & $53.62(1.22)$ & $72.51(8.25)$ & 139.98 (4.99) & $85.2(17.6)$ & $23.60(2.82)$ & $10.70(1.24)$ & $15.98(2.14)$ & $4.65(0.77)$ & $44.54(4.17)$ & $47.00(5.09)$ & $3.43(1.16)$ & $47.03(4.49)$ & $199.0(5.6)$ \\
\hline $\mathrm{VU}$ & $61.8(3.1)$ & $42.56(2.75)$ & $120.08(8.64)$ & $163.15(9.46)$ & $106.9(13.9)$ & $21.31(1.31)$ & $4.15(0.25)$ & $40.46(3.10)$ & $2.65(0.19)$ & $20.49(0.86)$ & $29.59(2.18)$ & $9.88(1.27)$ & $95.28(7.16)$ & $284.8(6.6)$ \\
\hline LP & $122.9(3.1)$ & $42.46(2.89)$ & $48.04(3.30)$ & $104.37(5.49)$ & $61.2(4.8)$ & $25.90(0.91)$ & $7.29(0.15)$ & $25.33(1.21)$ & $4.64(0.19)$ & $30.69(0.97)$ & $44.00(0.76)$ & $1.63(0.68)$ & $49.42(1.00)$ & $296.2(5.8)$ \\
\hline PLS & $41.8(9.4)$ & $18.70(11.97)$ & $20.70(1.87)$ & $58.88(7.42)$ & $121.4(15.2)$ & $17.92(0.33)$ & $38.16(1.78)$ & $20.21(0.83)$ & $85.21(3.74)$ & $68.95(2.88)$ & $60.16(4.63)$ & $1.37(1.37)$ & $67.86(3.19)$ & $436.4(42.4)$ \\
\hline SA & $36.6(7.3)$ & $19.92(4.22)$ & $26.84(3.57)$ & $54.47(5.49)$ & $140.3(10.9)$ & $10.84(0.42)$ & $54.76(2.36)$ & $44.08(2.17)$ & $30.30(1.63)$ & $81.26(3.27)$ & $57.54(2.45)$ & $21.63(1.02)$ & $76.06(2.47)$ & $699.3(17.3)$ \\
\hline SFA & $40.6(11.4)$ & $13.59(2.66)$ & $22.25(4.01)$ & $40.92(3.74)$ & $222.1(31.1)$ & $8.98(0.98)$ & $48.95(3.27)$ & $39.03(4.82)$ & $26.00(2.19)$ & $74.78(5.67)$ & $51.49(4.14)$ & $14.89(2.23)$ & $67.06(5.79)$ & 708.5 \\
\hline SR & $82.5(3.4)$ & $26.27(6.04)$ & $22.94(10.21)$ & $68.75(8.85)$ & $230.3(21.3)$ & $5.56(3.09)$ & $39.96(2.80)$ & $33.52(3.84)$ & $18.76(0.63)$ & $54.59(4.86)$ & $54.78(3.81)$ & $16.05(2.79)$ & $59.07(3.55)$ & $630.3(20.9)$ \\
\hline SMG & $46.3(7.5)$ & $29.46(6.70)$ & $27.99(6.62)$ & $62.22(9.02)$ & $226.6(23.9)$ & $6.13(0.39)$ & $36.34(1.94)$ & $32.90(1.76)$ & $19.95(1.19)$ & $46.46(2.12)$ & $58.71(2.81)$ & $26.78(1.33)$ & $51.23(2.89)$ & $662.3(28.6)$ \\
\hline SB & $35.1(9.9)$ & $20.78(4.33)$ & $33.87(1.82)$ & 55.71 (19.39) & $204.3(2.1)$ & $8.44(2.76)$ & $43.00(0.56)$ & $47.51(0.15)$ & $33.53(2.48)$ & $79.72(2.86)$ & $56.47(0.20)$ & $7.58(3.20)$ & $58.29(5.29)$ & $655.4(33.5)$ \\
\hline SFC & $54.9(6.1)$ & $25.80(6.13)$ & $34.33(3.19)$ & $76.58(17.84)$ & $226.2(16.8)$ & $4.15(1.84)$ & $41.81(0.54)$ & $37.26(2.25)$ & $19.90(0.85)$ & $51.43(1.76)$ & $56.31(0.82)$ & $28.60(1.74)$ & $57.79(0.08)$ & $556.2(29.6)$ \\
\hline SCU & $17.3(4.1)$ & $28.24(0.15)$ & $17.15(0.44)$ & $83.98(1.40)$ & $293.7(14.7)$ & $10.21(2.13)$ & $39.22(1.45)$ & $48.51(2.13)$ & $35.55(0.10)$ & $91.59(9.98)$ & $74.26(4.44)$ & $9.87(0.29)$ & $52.87(0.39)$ & $709.0(5.9)$ \\
\hline
\end{tabular}


Appendix 1 continued

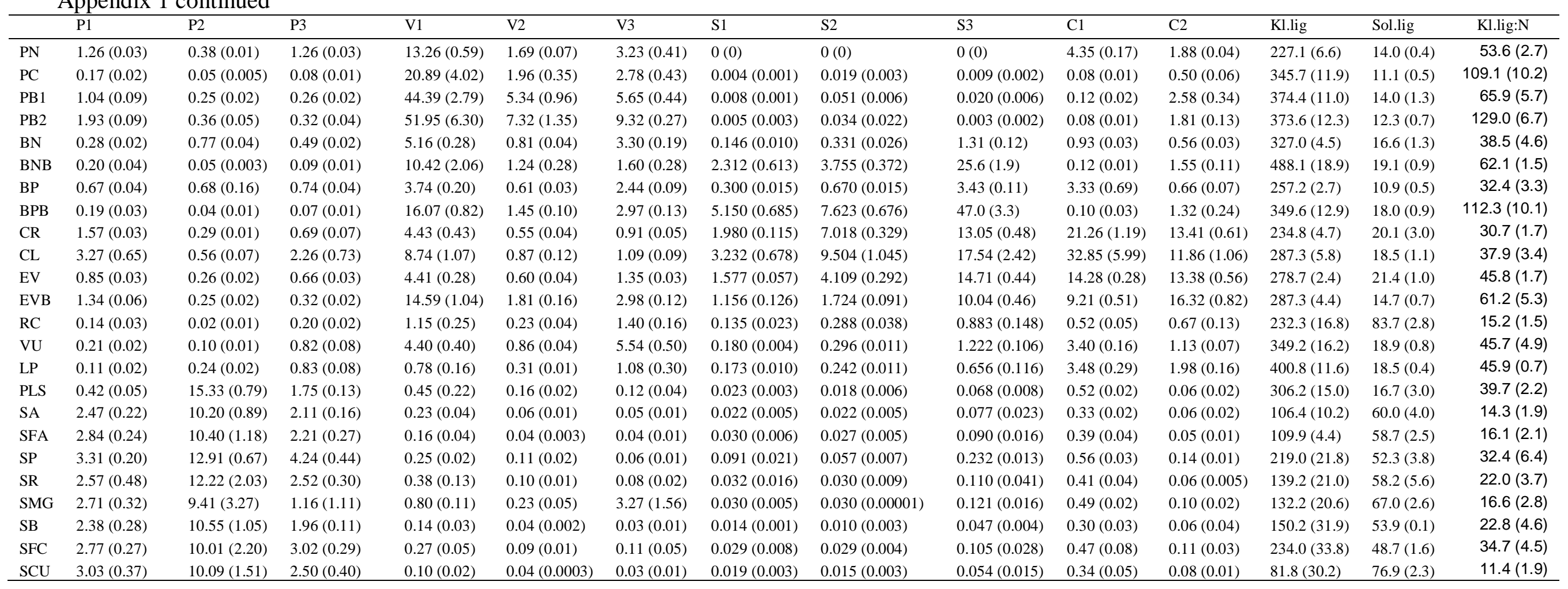




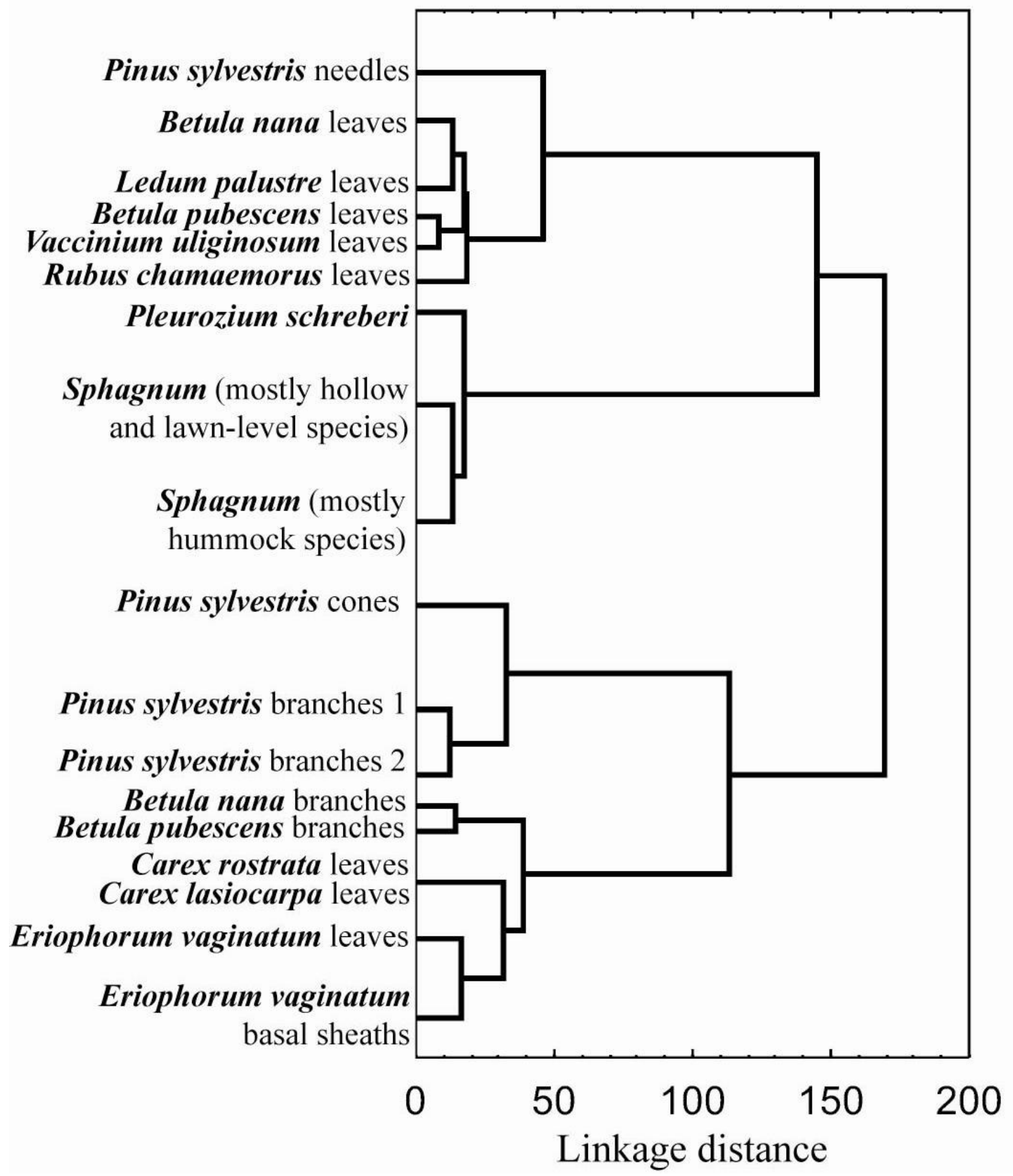

Appendix 2. Tree diagram from cluster analysis showing differences between litter types based on their chemical composition. Pinus sylvestris branches 1 , branches with diameter $\leq 1 \mathrm{~cm}$; Pinus sylvestris branches 2 , branches with diameter 1-2 $\mathrm{cm}$. 